\title{
Greenhouse gas emissions from intensively managed peat soils in an arable production system
}

Taft, Helen; Cross, Paul; Edwards-Jones, Gareth; Moorhouse, E.R.; Jones, David

\section{Agriculture, Ecosystems and Environment}

DOI:

10.1016/j.agee.2016.11.015

Published: 16/01/2017

Peer reviewed version

Cyswllt i'r cyhoeddiad / Link to publication

Dyfyniad o'r fersiwn a gyhoeddwyd / Citation for published version (APA):

Taft, H., Cross, P., Edwards-Jones, G., Moorhouse, E. R., \& Jones, D. (2017). Greenhouse gas emissions from intensively managed peat soils in an arable production system. Agriculture, Ecosystems and Environment, 237, 162. https://doi.org/10.1016/j.agee.2016.11.015

Hawliau Cyffredinol / General rights

Copyright and moral rights for the publications made accessible in the public portal are retained by the authors and/or other copyright owners and it is a condition of accessing publications that users recognise and abide by the legal requirements associated with these rights.

- Users may download and print one copy of any publication from the public portal for the purpose of private study or research.

- You may not further distribute the material or use it for any profit-making activity or commercial gain

- You may freely distribute the URL identifying the publication in the public portal ?

Take down policy

If you believe that this document breaches copyright please contact us providing details, and we will remove access to the work immediately and investigate your claim. 


\section{Accepted Manuscript}

Title: Greenhouse gas emissions from intensively managed peat soils in an arable production system

Author: Helen E. Taft Paul A. Cross Gareth Edwards-Jones Edwin R. Moorhouse Davey L. Jones

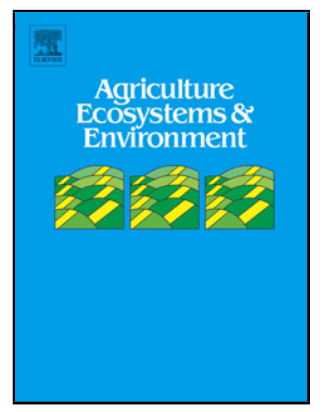

PII:

S0167-8809(16)30569-2

DOI: http://dx.doi.org/doi:10.1016/j.agee.2016.11.015

Reference: AGEE 5652

To appear in: Agriculture, Ecosystems and Environment

Received date: $\quad 28-4-2016$

Revised date: $\quad$ 14-11-2016

Accepted date: $\quad$ 20-11-2016

Please cite this article as: Taft, Helen E., Cross, Paul A., Edwards-Jones, Gareth, Moorhouse, Edwin R., Jones, Davey L., Greenhouse gas emissions from intensively managed peat soils in an arable production system.Agriculture, Ecosystems and Environment http://dx.doi.org/10.1016/j.agee.2016.11.015

This is a PDF file of an unedited manuscript that has been accepted for publication. As a service to our customers we are providing this early version of the manuscript. The manuscript will undergo copyediting, typesetting, and review of the resulting proof before it is published in its final form. Please note that during the production process errors may be discovered which could affect the content, and all legal disclaimers that apply to the journal pertain. 
Greenhouse gas emissions from intensively managed peat soils in an arable production system

Helen E. Taft ${ }^{\text {a, }}{ }^{*}$, Paul A. Cross ${ }^{\text {a }}$, Gareth Edwards-Jones ${ }^{\mathrm{a}, \dagger}$, Edwin R. Moorhouse ${ }^{\mathrm{b}}$, Davey L. Jones ${ }^{\text {a }}$

${ }^{a}$ School of Environment, Natural Resources and Geography, Deiniol Road, Bangor, Gwynedd, LL57 2UW, UK

${ }^{\mathrm{b}}$ G's Fresh, Barway, Cambs., CB7 5TZ, UK

* Corresponding author. Email address: $\underline{\text { h.taft@ bangor.ac.uk }}$

$\dagger$ Deceased 


\section{Highlights}

- We monitored annual $\mathrm{CO}_{2}, \mathrm{~N}_{2} \mathrm{O}$ and $\mathrm{CH}_{4}$ emissions from arable peat soils.

- Emissions were dominated by $\mathrm{CO}_{2}$ from $\mathrm{SOM}$ mineralization.

- Cumulative $\mathrm{N}_{2} \mathrm{O}$ emissions were important, and $\mathrm{CH}_{4}$ emissions negligible.

- Total emissions generally increased with an increase in SOM content.

- Intensive cultivation promotes loss of SOM and depletes the soil resource. 


\section{ABSTRACT}

Organic-rich, eutrophic peat soils (Histosols) represent a major store of carbon (C) within the terrestrial biosphere. However, these soils are also highly susceptible to damage, particularly when used for intensive agricultural production. Sustainable management of such soils is contingent upon improved understanding of the impact of their management on the environment. In this context, we report the first annual budget of greenhouse gas emissions from temperate peat soils under intensive horticultural production. Fluxes of $\mathrm{CO}_{2}, \mathrm{~N}_{2} \mathrm{O}$ and $\mathrm{CH}_{4}$ were measured using static chambers on three farms along an organic matter loss gradient ( 20\%, 35\%, and $\sim 70 \%$ soil organic matter (SOM) content respectively), under a number of commercially important crops in similar rotations. Cumulative annual fluxes of $\mathrm{CO}_{2}$ in fallow and cropped soils were large and ranged from $13.0 \pm 2.4$ to $30.9 \pm 2.5 \mathrm{t} \mathrm{CO}_{2}$-e $\mathrm{ha}^{-1} \mathrm{y}^{-1}$, showing a general increase with SOM, and on cropped compared to bare soils. Annual emissions of $\mathrm{N}_{2} \mathrm{O}$ varied from $5.0 \pm 0.7$ to $13.9 \pm 1.9 \mathrm{t} \mathrm{CO}_{2}$-e ha ${ }^{-1} \mathrm{y}^{-1}$, and $\mathrm{CH}_{4}$ from $-0.02 \pm 0.08$ to $0.04 \pm 0.02 \mathrm{t} \mathrm{CO}_{2}-\mathrm{e} \mathrm{ha}^{-1} \mathrm{y}^{-1}$; neither showed a significant relationship with either SOM content or cropping. Distinct seasonal patterns of $\mathrm{CO}_{2}$ and $\mathrm{N}_{2} \mathrm{O}$ fluxes were observed, corresponding to significant correlations between emissions and soil and air temperature, soil moisture content, water table depth, and soil nitrate on some soil types. No discernible seasonal pattern in $\mathrm{CH}_{4}$ fluxes was observed, and very few significant correlations with soil environmental variables were found. Compared to emissions estimates suggested in IPCC inventory guidelines for cultivated peat soils, the observed emissions in this study were relatively high, and net annual fluxes of $\mathrm{CO}_{2}$ and $\mathrm{CH}_{4}$ are equivalent to a loss of soil depth of 0.33 to $0.75 \mathrm{~cm} \mathrm{y}^{-1}$. We conclude that arable farming is promoting extreme mineralization of the soil's organic carbon reserves and that a change in land use or management regime is needed to protect and preserve this natural capital. 
Keywords: Carbon dioxide, Food security, Horticulture, Methane, Nitrous oxide, Soil nutrient cycling 


\section{Introduction}

Peat soils (Histosols) represent a major store of carbon (C) within the terrestrial biosphere (Limpens et al., 2008). While most studies of C loss have focused on non-agricultural peat soils, current evidence suggests that intensively cultivated lowland peats may also represent hotspots for greenhouse gas (GHG) emissions and related soil organic C (SOC) losses (Cannell et al., 1999; Dawson et al., 2010; Smith et al., 2007). Work on these arable peat systems has mainly focussed on quantifying $\mathrm{CO}_{2}$ emission and changes in SOC storage, largely neglecting emissions of $\mathrm{CH}_{4}$ and $\mathrm{N}_{2} \mathrm{O}$, and complete $\mathrm{GHG}$ budgets for organic soils under continuous arable management are extremely scarce (Evans et al., 2011; IPCC, 2014; Worrall et al., 2011). As GHG Emission Factors (EF) for arable mineral soils, or peat under managed grassland, are not likely to reflect emissions from these arable peats (due to differences in management regime and soil properties, for example), there is an urgent need to develop accurate and robust EFs for these agroecosystems. This is reinforced by their economic importance in terms of food security in many countries (Parish et al., 2008). Improving emissions estimates facilitates accurate inventorying at the national level, a legal requirement for emissions reduction target compliance in many countries, and an important step in identifying mitigation priorities (IPCC, 2006). Mitigating agricultural emissions could contribute substantially to overall reduction targets. For example, in 2013, agriculture was estimated to be the second-largest sector contributor to emissions in Europe (9.9\% $\mathrm{CO}_{2}$-e of total $\mathrm{EU}_{28}$ emissions), with direct agricultural soil emissions of $\mathrm{N}_{2} \mathrm{O}$ accounting for approximately $40 \%$ of this figure (EEA, 2015). Agricultural peat emissions at the national level are currently calculated using a default EF averaged over all temperate zones, with little recognition of regional differences in climate, peat soil characteristics and agricultural management practices when compared to the temperate-zone average. Consequently, soil $\mathrm{N}_{2} \mathrm{O}$ EFs in particular have been identified as a priority for refinement, 
dominating overall sources of uncertainty in EU GHG estimates since 1990 (EEA, 2015; Leip, 2010).

The sustainability of cropping on peat soils is an important consideration for longterm food security, with soil loss rates in drained and intensively cropped regions indicating that these practices are detrimental to the conservation of soil C stocks. Rates of soil loss from temperate lowland peats have been reported at 0.2 to $7.0 \mathrm{~cm} \mathrm{y}^{-1}$ (Richardson and Smith, 1977; Ewing and Vepreskas, 2006), with a recent estimate from UK East Anglian arable fens of 1.10 to $1.48 \mathrm{~cm} \mathrm{y}^{-1}$ between 1982 and 2004 (Dawson et al., 2010). Emissions of $\mathrm{CO}_{2}$ may constitute between $35 \%$ and $100 \%$ of peat subsidence C losses (Leifeld et al., 2011), but the literature remains unclear regarding the proportion of total SOC loss that can be attributed to other routes (principally, wind and water erosion, leaching, and crop adherence). Quantifying GHG emissions from arable peats under different management regimes can therefore contribute to estimates of future soil losses, and enable prioritisation of soil loss mitigation measures via the different routes of loss.

Factors influencing emissions from agricultural soils are numerous and interact in often complex ways; they include soil (e.g. moisture, temperature, porosity, substrate availability), climate (rainfall, temperature), and vegetation (yield, water uptake), which in turn are driven by human activities such as farm operations (Li, 2007). Often, a change in a single variable may simultaneously increase the emission of one GHG and result in the reduction of another (Smith et al., 2008). Whilst individual studies have been conducted and models created that identify the relative importance of these factors in driving agricultural soil emissions (e.g. Giltrap et al., 2010), quantification of emissions drivers requires further attention with regard to intensively managed agricultural peat soils.

The primary aim of this study was to quantify and compare emissions of $\mathrm{CO}_{2}, \mathrm{CH}_{4}$ and $\mathrm{N}_{2} \mathrm{O}$ from soils of comparatively high organic matter content ( $70 \% \mathrm{SOM}, \sim 35 \% \mathrm{SOM}$, 
and $\sim 20 \%$ SOM respectively, to $1 \mathrm{~m}$ depth), under a number of commercially important horticultural/arable crops. We also aimed to determine which soil and crop factors most strongly influenced GHG fluxes from these soils.

\section{Methods and materials}

\subsection{Study sites}

The study area was located in East Anglia, UK, and comprised drained lowland fen typified by flat topography (0-1\% slope) with long-term (1980-2013) mean annual rainfall of $621 \mathrm{~mm}$, mean annual temperature of $10.2^{\circ} \mathrm{C}$ (winter mean $4.4^{\circ} \mathrm{C}$, summer mean $16.4^{\circ} \mathrm{C}$ ), and mean annual sunshine of $1280 \mathrm{~h}$ (UK MetOffice, 2014). All sites have been under longterm horticultural/arable production in rotation since c. 1940, growing primarily vegetables (e.g. celery, leeks, lettuces, potatoes, red beet) and wheat. Details of management practices implemented during the monitoring period are provided in the supplementary material (Supplementary tables S.1-S.3).

Three farms (sites) were identified for monitoring on the basis of their contrasting soil organic matter content to $1 \mathrm{~m}$ depth: (1) Site 1 comprised the low SOC farm site (SOC $\mathrm{LOw}_{\text {) }}$ where the soils had a SOM content of $\sim 20 \%$; (2) Site 2 comprised the medium SOC farm site ( $\mathrm{SOC}_{\mathrm{MED}}$ ) where the soils had a SOM content of $\sim 35 \%$; (3) Site 3 comprised the high-SOC farm site $\left(\mathrm{SOC}_{\mathrm{HIGH}}\right)$ where the soils had a SOM content of $\sim 70 \%$. Experimental monitoring sites were selected from each farm using farm records to identify fields with typical commercial cropping rotations. Crops selected for study included: celery (Apium graveolens L.), red beet (Beta vulgaris L., grown in tandem with a cover crop of barley, Hordeum vulgare L.), lettuce (Lactuca sativa L.), radish (Raphanus sativus L.), and potato (Solanum tuberosum L.). Six fields (three at the $\mathrm{SOC}_{\mathrm{MED}}$ farm site, and three at the $\mathrm{SOC}_{\mathrm{HIGH}}$ farm site) 
were sampled monthly from April 2011 until June 2012, with a seventh field at the SOC $_{\text {LOW }}$ farm site added in June 2011.

One experimental sampling block $(6 \times 30 \mathrm{~m})$ was randomly positioned within each field (Fig. S.1). Blocks were located at least $10 \mathrm{~m}$ from field margins and areas of heavy vehicle trafficking were avoided. Each sampling block contained five randomised pairs of cropped (C) and bare (B) fallow plots $6 \times 6 \mathrm{~m}$ in size with the long axis of the block running parallel to the crop planting line. Inclusion of both cropped and bare plots enabled estimation of autotrophic vs. heterotrophic respiration (after Koerber et al., 2010). During the growing season the bare plots were covered with black geo-textile ground cover to suppress weed growth. Each $6 \times 6 \mathrm{~m}$ plot enclosed a $1 \mathrm{~m}$ buffer around its inner boundary to reduce edge effects of adjacent plots and field areas, leaving a $4 \times 4 \mathrm{~m}$ monitoring area containing one randomly positioned GHG monitoring collar.

\subsection{Seasonal greenhouse gas fluxes}

Monthly greenhouse gas measurements were undertaken at all sites. Closed, non-vented static chambers were used to monitor soil emissions of $\mathrm{N}_{2} \mathrm{O}$ and $\mathrm{CH}_{4}$. Cylindrical black polyethylene collars (internal dimensions $d=26.3 \mathrm{~cm}, h=19.8 \mathrm{~cm}$; PBSL, Colchester, UK) were inserted $12 \mathrm{~cm}$ into the soil and left in situ unless removed to allow tillage operations to take place. All vegetation was removed from within and surrounding the collar at installation at least $24 \mathrm{~h}$ before each sampling event. The static chambers fitting onto the collars consisted of white opaque polypropylene closed cylinders (internal dimensions $d_{1}=22.0 \mathrm{~cm}, d_{2}=$ $25.0 \mathrm{~cm}, h=26.3 \mathrm{~cm}$; CJK Packaging, Derbyshire, UK), with a rubber septum sampling port $7 \mathrm{~cm}$ from the top of the chamber, and an internal battery powered $25 \mathrm{~mm} 12 \mathrm{~V}$ fan (typical flow rate $=541 \mathrm{~min}^{-1}$; CPC Ltd., Leeds, UK). Chambers were inserted $4.5 \mathrm{~cm}$ into the top lip of the soil collar so that the flexible seal around the chamber rim formed an air-tight seal with 
the collar, giving a final enclosed headspace volume of $19.8 \mathrm{dm}^{3}$ (Fig. S.2). All chambers were vented for $>5$ min prior to collar attachment and GHG sampling.

The chamber headspace was sampled four times at approximately $10 \mathrm{~min}$ intervals, with the first gas sample taken immediately after chamber enclosure. Glass sample vials (20 ml) fitted with butyl rubber septa (QUMA Electronik \& Analytik GmbH, Wuppertal, Germany) were manually evacuated $(60 \mathrm{ml})$ prior to sampling. Gas samples were removed from the headspace of the static chambers using a $30 \mathrm{ml}$ syringe and a $21 \mathrm{G}, 5 \mathrm{~cm}$ needle. On insertion of the needle into the septum, the syringe was flushed twice then the sample taken and injected into the vial.

Gas samples were stored at room temperature in the dark until analysis. Sample analysis was within six weeks of collection using a gas chromatograph (Varian 450-GC, Bruker UK Ltd., Coventry, UK), equipped with a flame ionisation detector (FID, operated at $\left.120-125^{\circ} \mathrm{C}\right)$ and electron capture detector $\left(\mathrm{ECD}\right.$, operated at $\left.300^{\circ} \mathrm{C}\right)$, and attached to a QUMA QHSS ${ }^{\circledR}-40$ Headspace Sampler (QUMA Electronik \& Analytik GmbH, Wuppertal, Germany), which injected $2 \mathrm{ml}$ of sample into the GC. Gas standards with certified concentrations to within 2-10\% of their specification (STG Ltd., UK) were analysed concurrently with field samples. Sample concentrations of GHGs were calculated according to Levy et al. (2011).

Immediately following chamber measurements, soil $\mathrm{CO}_{2}$ emissions were measured within $10-30 \mathrm{~cm}$ of the outside of chamber collars using an EGM-4 portable infra-red gas analyser (IRGA; PP Systems Ltd., Hitchin, UK) equipped with an automatic SRC-1 soil respiration chamber (internal dimensions $d=10.35 \mathrm{~cm}, h=6.50 \mathrm{~cm}$; total volume $=$ $1694 \mathrm{ml})$, as described in Alm et al. (2007). Soil and air temperature (0-10 cm depth) were recorded at the time of sampling using a Checktemp1® temperature probe (accurate to \pm $0.3^{\circ} \mathrm{C}$; Hanna, Bedfordshire, UK). 
All GHG samples from a single field were taken within a $3 \mathrm{~h}$ period during daylight hours with all seven fields sampled over a $96 \mathrm{~h}$ period.

\subsection{Measurement of environmental variables}

A range of soil and crop samples were taken within $24 \mathrm{~h}$ of chamber and IRGA

measurements. In each plot, a randomly placed bulk density core $\left(V=100 \mathrm{~cm}^{3}\right)$ was used to collect soil from 0-5 cm and 0-10 cm depths. Soils were stored at $4{ }^{\circ} \mathrm{C}$ then homogenised before analysis. Soil moisture and bulk density were calculated after drying $\left(105^{\circ} \mathrm{C}, 24 \mathrm{~h}\right)$. A sub-sample of field-moist soil (0-5 cm depth) was used to extract plant available $\mathrm{NH}_{4}{ }^{+}$and $\mathrm{NO}_{3}{ }^{-}$with $0.5 \mathrm{M} \mathrm{K}_{2} \mathrm{SO}_{4}$ or $1 \mathrm{M} \mathrm{KCl}$ for $1 \mathrm{~h}(1: 5 \mathrm{w} / \mathrm{v})$, then soluble $\mathrm{N}$ concentrations determined with a Powerwave XS Microplate Spectrophotometer (BioTek UK, Bedfordshire, UK) using the colorimetric methods outlined in Mulvaney (1996) and Miranda et al. (2001) respectively. Soil $\mathrm{pH}$ was measured on field-moist soil $(0-10 \mathrm{~cm}$ depth $)$ in $0.01 \mathrm{M} \mathrm{CaCl}_{2}$ (1:1 w/v) following the method of Doran and Jones (1996). To estimate above-ground crop biomass during the growing season, five randomly selected plants were taken from near the sampling block in each field, their roots removed, and shoot fresh and dry $\left(80^{\circ} \mathrm{C},>48 \mathrm{~h}\right)$ weight determined. At harvest, shoots were additionally separated into 'harvested' and 'residue' portions, which were weighed and dried separately. Water table depth (to within $10 \mathrm{~cm}$ ) was measured at the field margin ditches perpendicular to the sampling block.

Additional soil samples were taken at each site in January 2012 to provide estimates of soil $\mathrm{C}$ and $\mathrm{N}$ stocks to $1 \mathrm{~m}$ depth. A bulk density core $\left(V=100 \mathrm{~cm}^{3}\right)$ was used to collect soil from the top $5 \mathrm{~cm}$ of each $10 \mathrm{~cm}$ depth, from 3 excavations at each site at $10 \mathrm{~m}$ intervals along a $20 \mathrm{~m}$ transect. Soil bulk density was calculated after drying $\left(105^{\circ} \mathrm{C}, 24 \mathrm{~h}\right)$, and $\mathrm{CN}$ analysis performed on dried samples ( $<2 \mathrm{~mm}$ fraction) using a LECO TruSpec CN analyzer (LECO Corp., St. Joseph, MI, USA). 


\subsection{Data cleaning and statistical analysis}

Measured concentrations of $\mathrm{N}_{2} \mathrm{O}$ and $\mathrm{CH}_{4}$ were converted to hourly gas fluxes $\left(\mu \mathrm{g} \mathrm{N} \mathrm{N}_{2} \mathrm{O}-\mathrm{N}\right.$ $\mathrm{m}^{-2} \mathrm{~h}^{-1}$ or $\mu \mathrm{g} \mathrm{CH} \mathrm{CH}_{4}-\mathrm{C} \mathrm{m}^{-2} \mathrm{~h}^{-1}$ ) using linear interpolation and the method described in Burden et al. (2013). Fluxes were visually examined and accepted for further analysis if the adjusted $R^{2}$ $\left(R_{\text {adj }}^{2}\right)$ was $\geq 0.70$ (after Ford et al., 2012, and Waddington et al., 2010), including the use of cleaned data where clear outliers were observed. Low fluxes were included in the analysis even if they had an $R_{\text {adj }}^{2}$ value of $<0.70$, to avoid a high flux bias in the data (Alm et al., 2007; Ford et al., 2012). Data cleaning resulted in $94 \%$ of $\mathrm{N}_{2} \mathrm{O}$ and $92 \%$ of $\mathrm{CH}_{4}$ individual flux curves being accepted for analysis. Soil respiration values were adjusted for diurnal temperature variation after Koerber et al. (2010), using the procedure described in Parkin and Kaspar (2003). We adjusted fluxes using Met Office Integrated Data Archive System (MIDAS) air temperature averaged for available stations within the local vicinity of each field site, and a $Q_{10}$ of 2.2 for peat soils (York, 2012). No information could be found for appropriate adjustment for diurnal flux variation of $\mathrm{N}_{2} \mathrm{O}$ or $\mathrm{CH}_{4}$, so the raw data values were used.

Mean cumulative fluxes over the whole measurement period were calculated separately for each $\mathrm{SOM}$ level $\left(\mathrm{SOC}_{\mathrm{LOW}}, \mathrm{SOC}_{\mathrm{MED}}, \mathrm{SOC}_{\mathrm{HIGH}}\right)$ and cropping combination by multiplying hourly values by 24 to give a daily flux, followed by linear stepwise interpolation of the flux values on known dates, then summing the resulting values over the required period (IPCC, 2000). Cumulative standard errors for each treatment were taken as the standard error of the cumulative means of individual chambers within that SOM-cropping (cropped vs. bare soil) type. Cumulative fluxes were calculated for the period $10^{\text {th }}$ June 2011 to $9^{\text {th }}$ June 2012 to allow inclusion of all sites for comparison. All cumulative flux estimates were converted to 100-year global warming potential $\left(G W P_{100}\right) \mathrm{CO}_{2}$ equivalents $\left(\mathrm{CO}_{2}\right.$-e $)$ according to the 
methodology outlined in IPCC (2000), allowing comparison between SOM-cropping types for total GWP and individual GHG GWPs, and comparison with UK GHG Inventory EFs (Webb et al., 2014).

Statistical analyses were performed using SPSS v. 20 (IBM, Inc.), with significance being accepted at $p \leq 0.05$ except where stated otherwise. Statistical analyses were performed separately on each SOM-cropping (cropped vs. bare soil) combination. Normality was tested using the Shapiro-Wilk test (Field, 2005), and non-normal data were log-transformed or square-root transformed; homogeneity of variances were tested using Levene's or Welch's test statistic. Cumulative fluxes of $\mathrm{CO}_{2}, \mathrm{~N}_{2} \mathrm{O}$, and total $G W P_{100}$ were compared using two-way ANOVA and Bonferroni Post-Hoc tests, using SOM\% and cropping as fixed factors. Cumulative $\mathrm{CH}_{4}$ fluxes showed heterogeneity of variances, so SOM\% and cropping effects were assessed separately using the Kruskall-Wallis test and Mann-Whitney U test respectively. Relationships between individual GHGs and environmental variables (soil temperature, MIDAS mean air temperature, measured air temperature, daily and 5-day cumulative rainfall, soil $\mathrm{N}$ concentrations, soil bulk density, soil $\mathrm{pH}$, and crop aerial biomass) were explored using Kendall's tau statistic $(\tau)$.

\section{Results}

\subsection{Weather conditions}

The mean annual air temperatures for the $\mathrm{SOC}_{\mathrm{LOW}}, \mathrm{SOC}_{\mathrm{MED}}$ and $\mathrm{SOC}_{\mathrm{HIGH}}$ sites were similar at $11.3,11.2$ and $11.0^{\circ} \mathrm{C}$, respectively during the monitoring period (Fig. 1a). Recorded mean annual soil temperatures were $13.2,13.0$ and $13.5^{\circ} \mathrm{C}$, respectively. The maximum recorded air temperature across the sites was 23.4 to $24.7^{\circ} \mathrm{C}$ (Jun. 2011) while the lowest was -7.2 to $-4.6^{\circ} \mathrm{C}$ (Feb.). The mean annual rainfall at the $\mathrm{SOC}_{\mathrm{LOW}}, \mathrm{SOC}_{\mathrm{MED}}$ and $\mathrm{SOC}_{\mathrm{HIGH}}$ sites was 588 , 588 and $612 \mathrm{~mm}$, respectively. Over the whole monitoring period, $\mathrm{SOC}_{\mathrm{HIGH}}$ was the coolest 
and wettest site; while $\mathrm{SOC}_{\mathrm{MED}}$ and $\mathrm{SOC}_{\mathrm{LOw}}$ had similar higher daily average temperature and lower cumulative rainfall. Peak rainfall events over the measurement period were moderate and similar across sites, with peak daily rainfall events of 20 to $23 \mathrm{~mm}$ observed.

\subsection{Seasonal patterns of greenhouse gas fluxes}

A pronounced seasonal pattern of soil respiration was observed at all three sites (Fig. 1b). The highest fluxes were recorded in the summer (Jun.-Sept.; 157 to $201 \mathrm{mg} \mathrm{CO} 2-\mathrm{C} \mathrm{m}^{-2} \mathrm{~h}^{-1}$ ) on cropped soils and 128 to $201 \mathrm{mg} \mathrm{CO}_{2}-\mathrm{C} \mathrm{m}^{-2} \mathrm{~h}^{-1}$ on bare soils) with the lowest fluxes seen in winter (Oct.-Feb.; 6 to $22 \mathrm{mg} \mathrm{CO}_{2}-\mathrm{C} \mathrm{m}^{-2} \mathrm{~h}^{-1}$ on cropped soils and -2.2 to $20 \mathrm{mg} \mathrm{CO}_{2}-\mathrm{C} \mathrm{m}^{-2}$ $\mathrm{h}^{-1}$ on bare soils). Net $\mathrm{CO}_{2}$ uptake was only observed briefly, at the $\mathrm{SOC}_{\mathrm{LOW}}$ site during October.

During most months, mean $\mathrm{N}_{2} \mathrm{O}$ emissions were considerably smaller in magnitude than $\mathrm{CO}_{2}$ emissions, even when corrected for GWP, but showed greater variability (Fig. 1c). Similarly to soil respiration, $\mathrm{N}_{2} \mathrm{O}$ emissions tended to be lower in the winter and higher during the summer. Peak mean fluxes were observed in spring and early summer (Apr.-Jun.; 601 to $1116 \mu \mathrm{g} \mathrm{N}_{2} \mathrm{O}-\mathrm{N} \mathrm{m}^{-2} \mathrm{~h}^{-1}$ on cropped soils and 489 to $1661 \mu \mathrm{g} \mathrm{N} \mathrm{N}_{2} \mathrm{O}-\mathrm{N} \mathrm{m}^{-2} \mathrm{~h}^{-1}$ on bare soils) with the exception of a peak of $\mathrm{N}_{2} \mathrm{O}$ from cropped soils at the $\mathrm{SOC}_{\mathrm{HIGH}}$ site in October. Generally, minimum mean fluxes were recorded in winter (Oct.-Feb.; -6.7 to $27.7 \mu \mathrm{g} \mathrm{N}_{2} \mathrm{O}-\mathrm{N}$ $\mathrm{m}^{-2} \mathrm{~h}^{-1}$ on cropped soils and -75.2 to $24.0 \mu \mathrm{g} \mathrm{N}_{2} \mathrm{O}-\mathrm{N} \mathrm{m}^{-2} \mathrm{~h}^{-1}$ on bare soils). Mean negative fluxes were recorded on only a few occasions, at the $\mathrm{SOC}_{\mathrm{LOw}}$ site (Jul. and Oct.) and $\mathrm{SOC}_{\mathrm{HIGH}}$ site (Feb.).

Mean $\mathrm{CH}_{4}$ fluxes were very small when compared to the other GHGs, both in absolute terms and when corrected for $G W P_{100}$. Fluxes oscillated around zero for the whole of the measurement period, with no apparent seasonal trend in emissions (Fig. 1d). $\mathrm{Net}^{\mathrm{CH}_{4}}$ uptake was observed on $39 \%$ of sampling occasions. 


\subsection{Seasonal patterns of soil $N$ availability}

At most sampling dates, mean soil concentrations of nitrate were generally higher than for ammonium (Fig. 1e, f). The pattern of soil nitrate concentration over time differed between sites, with peak levels observed in August at the $\mathrm{SOC}_{\mathrm{LOW}}$ site $(322 \pm 56 \mathrm{mg} \mathrm{NO}$ - $\mathrm{N}$ kg dry soil $\left.^{-1}\right)$, March at the $\mathrm{SOC}_{\mathrm{MED}}$ site $\left(227 \pm 53 \mathrm{mg} \mathrm{NO}_{3}-\mathrm{N} \mathrm{kg}\right.$ dry soil $\left.^{-1}\right)$, and October at the $\mathrm{SOC}_{\mathrm{HIGH}}$ site $\left(219 \pm 41 \mathrm{mg} \mathrm{NO}-\mathrm{N} \mathrm{kg}\right.$ dry soil $\left.{ }^{-1}\right)$. A peak in available nitrate was recorded at all sites from March to May. Differences in soil nitrate between cropped and bare soil plots were only observed on a few sampling dates. Where differences were seen these were mainly in the summer, when mean $\mathrm{NO}_{3}-\mathrm{N}$ tended to be lower in the cropped soil in comparison to the bare soil plots. Mean soil nitrate over the whole observation period was highest at the $\operatorname{SOC}_{\text {LOW }}$ site $\left(87 \pm 10 \mathrm{mg} \mathrm{NO}_{3}-\mathrm{N} \mathrm{kg}\right.$ dry soil $\left.{ }^{-1}\right)$, followed by the $\mathrm{SOC}_{\mathrm{HIGH}}$ site $(74 \pm 4 \mathrm{mg}$ $\mathrm{NO}_{3}-\mathrm{N} \mathrm{kg}$ dry soil $\left.{ }^{-1}\right)$, and lowest at the $\mathrm{SOC}_{\mathrm{MED}}$ site $\left(72 \pm 4 \mathrm{mg} \mathrm{NO} \mathrm{N}_{3}-\mathrm{N} \mathrm{kg}\right.$ dry soil $\left.{ }^{-1}\right)$.

Soil available $\mathrm{NH}_{4}-\mathrm{N}$ remained at a relatively low level throughout the observation period (Fig. 1f). Generally, the pattern of available $\mathrm{NH}_{4}-\mathrm{N}$ concentration was very similar at all sites, with no discernible differences between cropped and bare soils, apart from at the $\mathrm{SOC}_{\mathrm{MED}}$ site where cropped $\mathrm{NH}_{4}-\mathrm{N}$ was slightly lower during June in both years. Overall, mean soil ammonium concentrations were almost identical at the $\mathrm{SOC}_{\mathrm{LOW}}$ and $\mathrm{SOC}_{\mathrm{HIGH}}$ sites $\left(19 \pm 6\right.$ and $24 \pm 1 \mathrm{mg} \mathrm{NH}_{4}-\mathrm{N} \mathrm{kg}$ dry soil ${ }^{-1}$ respectively), and higher at the $\mathrm{SOC}_{\mathrm{MED}}$ site $(32 \pm$ $5 \mathrm{mg} \mathrm{NH} 4-\mathrm{N} \mathrm{kg}$ dry soil $\left.{ }^{-1}\right)$.

\subsection{Effect of environmental variables on GHG emissions}

Soil and air temperature both showed highly significantly positive correlations with soil $\mathrm{CO}_{2}$ flux at both the $\mathrm{SOC}_{\mathrm{MED}}$ and $\mathrm{SOC}_{\mathrm{HIGH}}$ sites, but showed no significant correlation at the $\mathrm{SOC}_{\text {LOw }}$ site (Table 1). In terms of the amount of variability explained by temperature, soil 
temperature was the best predictor of $\mathrm{CO}_{2}$ emission (15-27\% of variability), followed by mean daily air temperature (15-22\% of variability), with air temperature taken at the time of the flux measurement being the weakest predictor (13-19\% of variability). This relationship was consistent at both the $\mathrm{SOC}_{\mathrm{MED}}$ and $\mathrm{SOC}_{\mathrm{HIGH}}$ sites on both cropped and bare soils, and was generally stronger on cropped than bare soils.

Indicators of soil moisture were generally negatively associated with $\mathrm{CO}_{2}$ emission, with water table depth explaining the greatest proportion of variability in fluxes, but only at the cropped $\mathrm{SOC}_{\mathrm{MED}}$ and the $\mathrm{SOC}_{\mathrm{HIGH}}$ sites $(8 \%$ and $10-11 \%$ of variability respectively; Table 1; Fig. 2). Soil moisture content $\left(\mathrm{H}_{2} \mathrm{O}_{\mathrm{DW}}\right)$ accounted for a further 3-5\% of variability in soil respiration on cropped $\mathrm{SOC}_{\mathrm{MED}}$ and $\mathrm{SOC}_{\mathrm{HIGH}}$ soils and 5-8\% of variability on $\mathrm{SOC}_{\mathrm{MED}}$ and $\mathrm{SOC}_{\mathrm{HIGH}}$ soils without crops. Overall, daily rainfall was a poor predictor of $\mathrm{CO}_{2}$ emissions.

Soil nitrate, ammonium and total $\mathrm{N}$ were less consistent predictors of soil respiration, with the relationship varying between sites. At the $\mathrm{SOC}_{\mathrm{MED}}$ site, soil $\mathrm{N}$ variables were negatively associated with soil respiration but only explained $<3 \%$ of the variability in $\mathrm{CO}_{2}$ flux. In contrast, soil $\mathrm{N}$ variables were positively associated with $\mathrm{CO}_{2}$ emission at the SOC $\mathrm{LOW}_{\mathrm{L}}$ and $\mathrm{SOC}_{\mathrm{HIGH}}$ sites. A significant correlation on the $\mathrm{SOC}_{\mathrm{LOW}}$ site was only found between $\mathrm{NH}_{4}-\mathrm{N}$ and bare soil emission, but explained the highest proportion of variability (7\%). Soil bulk density and $\mathrm{pH}$ were poor predictors of $\mathrm{CO}_{2}$ emissions, accounting for $<5 \%$ of the variability in below-ground $\mathrm{CO}_{2}$ fluxes. Crop aerial biomass was only significantly correlated with soil respiration at the $\mathrm{SOC}_{\mathrm{HIGH}}$ site, but accounted for a large proportion (30\%) of variability in $\mathrm{CO}_{2}$ emissions.

Temperature variables were significantly positively correlated with soil $\mathrm{N}_{2} \mathrm{O}$ emissions, although more weakly than for soil respiration. Soil temperature significantly predicted $\mathrm{N}_{2} \mathrm{O}$ emission at all sites, explaining 4\%, 2-3\%, and 5-9\% of emissions from 
$\mathrm{SOC}_{\mathrm{LOW}}, \mathrm{SOC}_{\mathrm{MED}}$ and $\mathrm{SOC}_{\mathrm{HIGH}}$ sites respectively. Daily air temperature only significantly correlated with $\mathrm{N}_{2} \mathrm{O}$ emission at the $\mathrm{SOC}_{\mathrm{HIGH}}$ site, accounting for 3-5\% of variability in fluxes, however, this was a better predictor than air temperature recorded during the GHG monitoring period.

Soil moisture variables were negatively associated with $\mathrm{N}_{2} \mathrm{O}$ emission, but only in a few categories, and only weakly compared to $\mathrm{CO}_{2}$ emission predictors. Water table depth accounted for $4-5 \%$ of variability at the $\mathrm{SOC}_{\mathrm{HIGH}}$ site, while soil moisture content explained $1-2 \%$ of variability in fluxes on the $\mathrm{SOC}_{\mathrm{MED}}$ and $\mathrm{SOC}_{\mathrm{HIGH}}$ bare soils, and daily rainfall explained $\leq 1 \%$ of variability across all sites. Soil $\mathrm{N}$ variables were also weaker predictors of $\mathrm{N}_{2} \mathrm{O}$ than $\mathrm{CO}_{2}$ emission, explaining only $1-2 \%$ of variability in fluxes. Soil bulk density and $\mathrm{pH}$ were both very weak predictors of $\mathrm{N}_{2} \mathrm{O}$ emission. Crop aerial biomass was only significantly associated with fluxes at the $\mathrm{SOC}_{\mathrm{LOW}}$ site, but accounted for $44 \%$ of variability in emissions.

Only a small number of environmental variables measured here were significantly associated with methane flux, and only weakly so. Of these, the most significant was soil nitrate which was positively correlated with $\mathrm{CH}_{4}$ efflux on bare $\mathrm{SOC}_{\mathrm{LOw}}$ soils, explaining 5\% of the flux variability.

\subsection{Cumulative GHG emissions}

Table 2 shows annual cumulative emissions of $\mathrm{CO}_{2}, \mathrm{~N}_{2} \mathrm{O}, \mathrm{CH}_{4}$ and overall $G W P_{100}$. Similarly to seasonal emissions, $\mathrm{CO}_{2}$ represented the largest annual flux from all soil types on both cropped and bare soil plots, ranging from 74 to $80 \%$ of total $G W P_{100}$ on cropped soils to 61 to $80 \%$ of total $G W P_{100}$ on soils without crops. $\mathrm{N}_{2} \mathrm{O}$ represented a smaller but still substantial annual emission, of between 20 and $26 \%$ of $G W P_{100}$ on cropped soils and 
20 and $39 \%$ of emissions on bare soils. On all sites, cumulative methane emission was negligible, comprising $<0.5 \%$ of annual emissions.

On both cropped and bare soils, cumulative $G W P_{100}$ was lowest at the $\mathrm{SOC}_{\mathrm{LOw}}$ site, highest at the $\mathrm{SOC}_{\mathrm{MED}}$ site, and intermediate at the $\mathrm{SOC}_{\mathrm{HIGH}}$ site (Table 2). At all sites, total cropped emission was greater than bare soil emission. Two-way ANOVA showed a significant main effect of both SOM content $(F=12.254, p<0.001)$ and cropping $(F=4.882, p<0.05)$ on cumulative $G W P_{100}$ (Table 3$)$. No interaction effects between SOM\% and cropping were evident. Bonferroni Post-Hoc tests identified a highly significant increase in $G W P_{100}$ between the $\mathrm{SOC}_{\mathrm{LOW}}$ and $\mathrm{SOC}_{\mathrm{MED}}$ sites $(p<0.001)$, but the decline in $G W P_{100}$ between $\mathrm{SOC}_{\mathrm{MED}}$ and $\mathrm{SOC}_{\mathrm{HIGH}}$ sites proved non-significant.

Patterns of annual $\mathrm{CO}_{2}$ emission broadly followed that of annual $G W P_{100}$ (Table 2). Cropping had a significant main effect on cumulative $\mathrm{CO}_{2}$ emissions, with higher mean fluxes from cropped plots at all three sites $(p<0.01$; Table 3). A significant main effect was also observed between annual $\mathrm{CO}_{2}$ emission and $\mathrm{SOM} \%(p<0.001)$. No significant interaction effect on cumulative $\mathrm{CO}_{2}$ emission was found between cropping and SOM content. However, the response of cumulative emissions to increasing SOM content differed according to cropping: on bare soils, total $\mathrm{CO}_{2}$ emission increased from $\mathrm{SOC}_{\mathrm{LOW}}$ to $\mathrm{SOC}_{\mathrm{HIGH}}$ sites; but on cropped soils, total annual emission increased from $\mathrm{SOC}_{\mathrm{LOW}}$ to $\mathrm{SOC}_{\mathrm{MED}}$ sites, then declined slightly at the $\mathrm{SOC}_{\mathrm{HIGH}}$ site (Table 2). Bonferroni Post-Hoc tests identified the increase in annual $\mathrm{CO}_{2}$ emission between $\mathrm{SOC}_{\mathrm{LOw}}$ and $\mathrm{SOC}_{\mathrm{MED}}$ sites as highly significant $(p$ $<0.01$ ), but not the difference between $\mathrm{SOC}_{\mathrm{MED}}$ and $\mathrm{SOC}_{\mathrm{HIGH}}$ sites.

On both bare and cropped soils, cumulate annual $\mathrm{N}_{2} \mathrm{O}$ emission was highest at the $\mathrm{SOC}_{\mathrm{MED}}$ site, lowest at the $\mathrm{SOC}_{\mathrm{LOW}}$ site, and intermediate at the $\mathrm{SOC}_{\mathrm{HIGH}}$ site, while no distinct pattern in annual emission relative to cropping was evident (Table 2). Results of the two-way ANOVA supported these observations: SOM\% significantly influenced cumulative 
$\mathrm{N}_{2} \mathrm{O}$ emission $(p<0.01)$, but cropping did not (Table 3). No significant interaction effects were observed between SOM\% and cropping. In contrast to annual $\mathrm{CO}_{2}$ emission, Bonferroni Post-Hoc tests identified a significant difference between annual $\mathrm{N}_{2} \mathrm{O}$ emission at the $\mathrm{SOC}_{\mathrm{MED}}$ and $\mathrm{SOC}_{\mathrm{HIGH}}$ sites $(p=0.01)$, but not between the $\mathrm{SOC}_{\mathrm{LOW}}$ and $\mathrm{SOC}_{\mathrm{HIGH}}$ sites.

The effects of SOM content and cropping on annual $\mathrm{CH}_{4}$ fluxes were assessed using the non-parametric Kruskall Wallis test and Mann-Whitney U test, respectively. No significant effects of either variable on annual $\mathrm{CH}_{4}$ emission were identified.

\subsection{Soil C and N stocks}

Estimates of soil $\mathrm{C}$ and $\mathrm{N}$ stocks to $1 \mathrm{~m}$ depth for each of the study sites are shown in Table 4.

Soil C content at the $\mathrm{SOC}_{\mathrm{LOW}}$ site varied between 16.7 and $19.1 \%$ in the upper $40 \mathrm{~cm}$ of soil, below which it sharply declined to between 3.8 and $8.7 \%$. Soil $\mathrm{N}$ content at the $\mathrm{SOC}_{\mathrm{LOw}}$ site followed a similar pattern $(1.2$ to $1.4 \%$ in the upper $40 \mathrm{~cm}$, declining to 0.3 to $0.7 \%$ below the $40 \mathrm{~cm}$ layer). $\mathrm{C}: \mathrm{N}$ ratios of individual $10 \mathrm{~cm}$ soil layers varied between 11.8 to 15.4 at this site, averaging 14.0 in the top $40 \mathrm{~cm}$ soil and 13.1 in the $40-100 \mathrm{~cm}$ layer.

The vertical profiles of soil $\mathrm{C}$ and $\mathrm{N}$ content at the $\mathrm{SOC}_{\mathrm{MED}}$ and $\mathrm{SOC}_{\mathrm{HIGH}}$ sites were comparable, but differed distinctly in the upper profile from those of the $\mathrm{SOC}_{\mathrm{LOW}}$ site. Both soil $\mathrm{C}$ and $\mathrm{N}$ content were highest at c. $20-70 \mathrm{~cm}$ depth, lowest at below c. $70 \mathrm{~cm}$, and intermediate in the top $20 \mathrm{~cm}$ soil (Table 4$)$. Soil $\mathrm{C}$ and $\mathrm{N}$ content $(0-20 \mathrm{~cm}$ depth) were only marginally higher at $\mathrm{SOC}_{\mathrm{HIGH}}$ that at $\mathrm{SOC}_{\mathrm{MED}}(34.9$ and $33.4 \% \mathrm{C}$, and 2.1 and $2.0 \% \mathrm{~N}$ respectively). However, $\mathrm{C}$ and $\mathrm{N} \%$ (20-70 $\mathrm{cm}$ depth) were on average notably higher at $\mathrm{SOC}_{\mathrm{HIGH}}$ than $\mathrm{SOC}_{\mathrm{MED}}(47.9$ and $38.6 \% \mathrm{C}$, and 2.7 and $2.2 \% \mathrm{~N}$ respectively), as were $\mathrm{C}$ and $\mathrm{N} \%$ below this depth (17.3 and $1.6 \% \mathrm{C}$, and 1.0 and $0.1 \% \mathrm{~N}$ respectively). $\mathrm{C}: \mathrm{N}$ ratios of 
individual $10 \mathrm{~cm}$ soil layers were more variable than at $\mathrm{SOM}_{\mathrm{LOw}}$, at between 9.7 and 24.6 at the $\mathrm{SOC}_{\mathrm{MED}}$ site and 15.1 and 19.5 at the $\mathrm{SOC}_{\mathrm{HIGH}}$ site.

Vertical bulk density profiles also differed between the $\mathrm{SOC}_{\mathrm{LOw}}$ site (increasing from 0.76 to $0.99 \mathrm{~g} \mathrm{~cm}^{-3}$ in the top $50 \mathrm{~cm}$ soil, then falling to $0.61 \mathrm{~g} \mathrm{~cm}^{-3}$ at $90 \mathrm{~cm}$ depth) and the $\mathrm{SOC}_{\mathrm{MED}}$ and $\mathrm{SOC}_{\mathrm{HIGH}}$ sites (both showing similar profiles which declined from c. $0.37 \mathrm{~g} \mathrm{~cm}^{-3}$ at $0 \mathrm{~cm}$ depth to c. $0.18 \mathrm{~g} \mathrm{~cm}^{-3}$ at $50 \mathrm{~cm}$ depth, then increased to a maximum of c. $1.36 \mathrm{~g} \mathrm{~cm}^{-3}$ at $90-100 \mathrm{~cm}$ depth).

The combined effect of vertical bulk density profiles and vertical $\mathrm{C}$ and $\mathrm{N} \%$ distributions, resulted in soil $\mathrm{C}$ and $\mathrm{N}$ stock profiles that generally declined with depth at all sites, although this occurred at different rates between sites. Total soil C stock $(0-100 \mathrm{~cm})$ was $787.5 \mathrm{t} \mathrm{ha}^{-1}$ at the $\mathrm{SOC}_{\text {LOw }}$ site, $907.0 \mathrm{tha}^{-1}$ at the $\mathrm{SOC}_{\text {MED }}$ site, and $953.7 \mathrm{tha}^{-1}$ at the $\mathrm{SOC}_{\mathrm{HIGH}}$ site. Total soil N stock $(0-100 \mathrm{~cm})$ was $57.0 \mathrm{t} \mathrm{ha}^{-1}\left(\mathrm{SOC}_{\mathrm{LOW}}\right.$ site $), 53.1 \mathrm{t} \mathrm{ha}^{-1}$ $\left(\mathrm{SOC}_{\mathrm{MED}}\right.$ site) and $57.4 \mathrm{tha}^{-1}\left(\mathrm{SOC}_{\mathrm{HIGH}}\right)$ respectively.

\section{Discussion}

\subsection{Seasonal and cumulative annual GHG emissions}

Despite the importance in horticultural production of eutrophic Histosols, we are not aware of any studies that have monitored a full annual cycle of GHG emissions from Histosols under continuous intensive horticultural management. Annual emissions in this study were dominated by $\mathrm{CO}_{2}$, followed by $\mathrm{N}_{2} \mathrm{O}$, whilst $\mathrm{CH}_{4}$ emissions were small. This is similar to the pattern of GHG emissions found in other studies of disturbed peat soils (Elder and Lal, 2008; Maljanen et al., 2004). Cumulative annual soil respiration rates from this study were high in comparison to some previous studies (6.9 to $20.0 \mathrm{t} \mathrm{CO}_{2}-\mathrm{e} \mathrm{ha}{ }^{-1} \mathrm{y}^{-1}$, Kasimir-Klemedtsson et al., 1997; Maljanen et al., 2004), but considerably lower than those found by other authors (44 to 122 t CO$_{2}-\mathrm{e} \mathrm{ha}^{-1} \mathrm{y}^{-1}$, Elder and Lal, 2008; Elsgaard et al., 2012). Differences may be 
attributable to post-harvest microbial respiration responses to plant residue breakdown, with a large quantity of available residue in the Elder and Lal (2008) study (maize crop), compared to those in the former studies (barley crops) and this study (various relatively low-growing crops). Site sensitivity to changes in soil temperature can also be a powerful driver of respiration, and has been found to differ depending on local soil and other environmental factors (e.g. Elsgaard et al., 2012).

Mean cropped $\mathrm{CO}_{2}$ emissions were greater than mean bare soil emissions, but only by a relatively small amount, with the majority of soil respiration (58 to $96 \%$ on a per-field basis) a result of microbial rather than root respiration. The proportion of respiration, as root respiration, found here showed greater variability than the $35-45 \%$ reported by Kasimir-Klemedtsson et al. (1997), but was of similar magnitude on all but the $\mathrm{SOC}_{\mathrm{HIGH}}$ site. This can perhaps be attributed to high rates of microbial respiration at the $\mathrm{SOC}_{\mathrm{HIGH}}$ site minimising the relative importance of root respiration within the total soil respiration budget. However, we were unable to account for possible priming effects in this study (of previous crops on the bare soil plots, or of present crops on cropped plots), limiting the degree to which this interpretation may be applied to these sites (Kuzyakov et al., 2000; Kuzyakov, 2010). It would be useful for future studies of these soils to include an estimate of the magnitude of any priming effects on relative soil decomposition rates, to aid differentiation between autotrophic vs. heterotrophic respiration contributions to total $\mathrm{CO}_{2}$ emission, particularly in relation to different individual crops, and cropping rotations. Discerning interaction effects between cropping (cropped vs. bare soils) and SOM content relative to $\mathrm{CO}_{2}$ and other GHG emissions was difficult in this study. Although cropping rotations were similar on all soil types, thus allowing categorisation as horticultural or intensive arable sites, cropping rotations were not identical (Supplementary tables S.1-S.3). Ideally, future work would aim to compare identically timed cropping rotations on soils of differing OM content, 
to give a more robust comparison of emission factors. The present study rather contributes a general indication of the magnitude and patterns of emissions from these sites.

This study found a significant positive association between $\mathrm{CO}_{2}$ emission and temperature and a negative association with water table depth at the cropped $\mathrm{SOC}_{\mathrm{MED}}$ and the $\mathrm{SOC}_{\mathrm{HIGH}}$ sites. The relationship between temperature and $\mathrm{SOM}$ oxidation is well documented (Dawson and Smith, 2007), and many studies have found soil and air temperature to be among the strongest predictors of soil respiration rate (e.g. Elsgaard et al., 2012; EstopAragonés and Blodau, 2012; Maljanen et al., 2001, 2002). Lowering the water table is also commonly associated with higher $\mathrm{CO}_{2}$ flux from peat soils (Kechavarzi et al., 2007; Maljanen et al., 2001). It is therefore possible that raising the height of the water table closer to the soil surface may help reduce $\mathrm{CO}_{2}$ emissions from these soils (e.g. Hatala et al., 2012). While this is unlikely to significantly impact on reducing $\mathrm{CH}_{4}$ emissions, it may increase $\mathrm{N}_{2} \mathrm{O}$ emissions, particularly if $\mathrm{N}$ derived from SOM mineralization or fertilisers are leached into this zone (e.g. Boon et al., 2014).

The maximum rate of $\mathrm{N}_{2} \mathrm{O}$ emissions observed here were generally lower than previous reports for vegetable crops, although our minimum fluxes were similar. For example, previous studies from temperate and boreal arable Histosols have measured $\mathrm{N}_{2} \mathrm{O}$ fluxes up to $7083 \mu \mathrm{g} \mathrm{N} \mathrm{N}_{2} \mathrm{O}-\mathrm{N} \mathrm{m}^{-2} \mathrm{~h}^{-1}$, although the mean flux tends to fall within the range of 30 to $3000 \mu \mathrm{g} \mathrm{N}_{2} \mathrm{O}-\mathrm{N} \mathrm{m}^{-2} \mathrm{~h}^{-1}$ (Elder and Lal, 2008; Flessa et al., 1998; Maljanen et al., 2002; Regina et al., 2004; Rochette et al., 2010; Weslien et al., 2012). The pattern of seasonal $\mathrm{N}_{2} \mathrm{O}$ emissions observed (peaks in spring and late summer/early autumn; lower emissions during winter) is similar to other studies on peat soils, where $\mathrm{N}_{2} \mathrm{O}$ peaks have been observed in response to mineral $\mathrm{N}$ application, cultivation, or post-harvest residue input (Elder and Lal, 2008; Rochette et al., 2010). At our study sites, crop establishment operations (tillage, mineral $\mathrm{N}$ application, irrigation, planting) were often practiced together over several days 
prior to measuring emissions (Supplementary tables S.1-S.3), so it is difficult to disaggregate the relative importance of individual management practices to peaks of $\mathrm{N}_{2} \mathrm{O}$. Field operations varied in their intensity or application rate (e.g. ploughing depth, fertiliser application rate) and timing relative to the timing of emissions measurements. Given that the response of $\mathrm{N}_{2} \mathrm{O}$ peaks to different field operations can vary in duration and intensity, particularly when interacting factors such as rainfall events and soil temperature are considered (e.g. De Klein and Harvey, 2013), it was not possible in this study to reliably disentangle individual effects (e.g. assigning individual peaks to particular fertiliser events). It is also possible that differing fertiliser rates at the three sites due to crop requirements influenced $\mathrm{N}_{2} \mathrm{O}$ emissions more than SOM\%, although this is dependent on priming effects and whether $\mathrm{N}$ supply is in excess of crop demand (e.g. Ye et al., 2016). Therefore, similarly to $\mathrm{CO}_{2}$ emissions, $\mathrm{N}_{2} \mathrm{O}$ emissions should be interpreted as a general indication of magnitude and seasonal patterns at similar sites. To aid refinement of $\mathrm{N}_{2} \mathrm{O}$ EFs, we recommend that future research should focus on capturing variability in emissions at a finer temporal scale across a range of SOM contents and cropping regimes, preferably over a multi-year monitoring campaign. This approach reduces the uncertainty associated with missing emissions peaks (resulting in underestimation of cumulative fluxes and soil $\mathrm{N}$ loss $\%$ ), and that associated with linear interpolation of high and low fluxes at a lower resolution temporal scale (resulting in overestimation of cumulative fluxes and soil $\mathrm{N}$ loss \%). Combining field measurements of key management events and environmental variables with process-based modelling (e.g. Brown et al., 2002; Chen et al., 2008; Smith et al., 2010), or finding suitable proxies for annual emissions (e.g. Ye et al., 2016), offers a further route to improving emissions estimates for intensively managed peat soils.

Methane emissions from temperate and boreal cropped and bare peat soils tend to be low (-0.15 to 0.25 t CO$_{2}$-e ha ${ }^{-1} \mathrm{y}^{-1}$, e.g. Elder and Lal, 2008; Kasimir-Klemedtsson et al., 
1997; Maljanen et al., 2002). Whilst these emissions are from cereal crops rather than vegetable crops, the emissions in this study $\left(-0.11 \pm 0.04\right.$ to $\left.0.10 \pm 0.10 \mathrm{t} \mathrm{CO}_{2}-\mathrm{e} \mathrm{ha}^{-1} \mathrm{y}^{-1}\right)$ are of a comparable magnitude. Such low emissions are typically found at sites such as ours, where top-soils are well-mixed, and moist but unsaturated, indicating predominantly aerobic conditions which favour methanotrophic rather than methanogenic microorganism activity (Le Mer and Roger, 2001).

\subsection{Comparison with IPCC default EFs}

The most recently published UK National Greenhouse Gas Inventory (Webb et al., 2014) uses the IPCC (2000) default emission factors (EFs) with some UK-specific modifications, to estimate $\mathrm{CO}_{2}, \mathrm{~N}_{2} \mathrm{O}$ and $\mathrm{CH}_{4}$ emissions from cultivated Histosols, providing annual estimates equivalent to 3.99 to $46.90 \mathrm{t} \mathrm{CO}_{2}-\mathrm{e} \mathrm{ha}^{-1} \mathrm{y}^{-1}$ carbon dioxide, $3.90{\mathrm{t} \mathrm{CO}_{2}-\mathrm{e} \mathrm{ha}}^{-1} \mathrm{y}^{-1}$ nitrous oxide, and 'negligible' methane emissions.

Mean cumulative annual $\mathrm{CO}_{2}$ emissions in this study were within the upper range estimated using the IPCC method. The soils at the study sites have been under cultivation for at least 50 years, so based on the premise that well-aerated, homogenised peats tend to be less reactive than relatively undisturbed Histosols, lower rates of emission might be expected. However, the characteristics of the peats in this study are intermediate between the description given for the lower IPCC emission rate $(<1 \mathrm{~m}$ depth, $<12 \%$ SOC) and the higher emission rate (> $1 \mathrm{~m}$ depth, $>12 \%$ SOC), so our intermediate emissions fit well with the predicted emission factors.

Estimated annual $\mathrm{N}_{2} \mathrm{O}$ emissions in this study varied from 1.51 to $15.79 \mathrm{t} \mathrm{CO}_{2}-\mathrm{e} \mathrm{ha}^{-1}$ $\mathrm{y}^{-1}$ on a per-field basis, and in all but one field were two to four times greater than the IPCCestimated default value. At a national scale, the IPCC (2000) method sums the emissions from peat cultivation with emissions from mineral fertiliser application and crop residue 
application (each $1.25 \%$ of applied $\mathrm{N}$ ). While insufficient crop residue data is available to allow calculation of accurate residue EFs from the study sites, mineral N EFs at the study sites after deducting the IPCC (2000) Histosol EF were estimated at between 0 and $27 \%$ of N applied during the annual emission calculation period, or between 0 and $14 \%$, if $\mathrm{N}$ applied immediately prior to the first sampling date in April 2011 is included (Supplementary tables S.1-S.3). This assumes that all $\mathrm{N}_{2} \mathrm{O}$ emissions were directly caused by mineral $\mathrm{N}$ application, but does not take account of crop residue input influences. Given the typically low total $\mathrm{N}$ content of the salad crops that are commonly grown on these sites, it is unlikely that residue $\mathrm{N}$ would account for a substantial portion of annual emissions, although residue input could substantially contribute to priming effects (Kuzyakov et al., 2000). It is possible therefore that the IPCC default EF of $1.25 \%$ of applied N may underestimate emissions at some SOM-rich sites; this requires further clarification.

Comparison of $\mathrm{N}_{2} \mathrm{O}$ fluxes at the study sites with estimates of $\mathrm{N}$ stocks to $1 \mathrm{~m}$ depth (Table 4) suggest that only a small percentage of soil $\mathrm{N}$ is lost annually as direct $\mathrm{N}_{2} \mathrm{O}$ emission as measured here $\left(<0.1 \%\right.$ of the total $\mathrm{N}$ stock at all sites, or 3.1 to $\left.32.4 \mathrm{~kg} \mathrm{~N} \mathrm{ha}^{-1}\right)$, but that the potential for nitrogen loss via other direct and indirect routes is substantial, with an estimated 7.9 to $10.1 \mathrm{t} \mathrm{N} \mathrm{ha}^{-1}$ stored in the top $10 \mathrm{~cm}$ of soil alone. Total theoretical $\mathrm{N}$ loss accompanying $\mathrm{C}$ loss during $\mathrm{SOM}$ mineralization can be estimated from $\mathrm{CO}_{2}$ emissions and soil $\mathrm{C}: \mathrm{N}$ ratios (Tables 2 and 4 respectively). If we assume that $\mathrm{CO}_{2}$ emissions are generated in the top soil $(0-10 \mathrm{~cm})$ only, theoretical $\mathrm{N}$ loss from the top soil would be between 245.7 and $363.8 \mathrm{~kg} \mathrm{ha}^{-1} \mathrm{y}^{-1}$ at the $\mathrm{SOM}_{\text {LOW }}$ site, 311.5 to $617.8 \mathrm{~kg} \mathrm{ha}^{-1} \mathrm{y}^{-1}$ at the $\mathrm{SOM}_{\mathrm{MED}}$ site, and 326.4 and $661.6 \mathrm{~kg} \mathrm{ha}^{-1} \mathrm{y}^{-1}$ at the $\mathrm{SOM}_{\mathrm{HIGH}}$ site. Conversely, if we assume that $\mathrm{CO}_{2}$ is generated from the entire cultivated layer $(0-40 \mathrm{~cm})$, theoretical $\mathrm{N}$ loss from the top soil would be slightly higher at the $\mathrm{SOM}_{\mathrm{LOW}}$ site $\left(253.2\right.$ to $374.9 \mathrm{~kg} \mathrm{ha}^{-1} \mathrm{y}^{-1}$ ), but slightly lower at $\mathrm{SOM}_{\mathrm{MED}}$ and $\mathrm{SOM}_{\mathrm{HIGH}}$ sites (308.5 to $611.9 \mathrm{~kg} \mathrm{ha}^{-1} \mathrm{y}^{-1}$, and 312.6 and $633.6 \mathrm{~kg} \mathrm{ha}^{-1} \mathrm{y}^{-1}$ 
respectively). Further, fertiliser $\mathrm{N}$ input can be added to these figures to compute theoretical total available $\mathrm{N}$ (excluding any residue $\mathrm{N}$ inputs). If $\mathrm{N}_{2} \mathrm{O}$ EFs are then calculated as a proportion of total available $\mathrm{N}$ on a per-field basis, gaseous $\mathrm{N}_{2} \mathrm{O}$ losses are estimated at between $0.5 \%$ and $5.4 \%$ of total available $\mathrm{N}$, i.e. still a relatively low proportion of total available $\mathrm{N}$.

Observed $\mathrm{CH}_{4}$ emissions (-0.11 to $0.10 \mathrm{t} \mathrm{CO}_{2}-\mathrm{e} \mathrm{ha}^{-1} \mathrm{y}^{-1}$ on a per-field basis) can be considered within the 'negligible' range described by the IPCC (2000). Further modification of methane EFs from the soil surface is therefore unnecessary when predicting emissions from these sites.

\subsection{Soil loss rates}

Using annual $\mathrm{C}$ budget calculations, mean soil bulk density and soil $\mathrm{C}$ values from our three study sites (Table 4), cumulative net gaseous C losses (Table 2) represent an average annual soil loss rate of 0.41 to $0.61 \mathrm{~cm}$ at the $\mathrm{SOC}_{\mathrm{LOw}}$ site, 0.33 to $0.60 \mathrm{~cm}$ at the $\mathrm{SOC}_{\mathrm{MED}}$ site, and 0.37 to $0.75 \mathrm{~cm}$ at the $\mathrm{SOC}_{\mathrm{HIGH}}$ site. While these values are low compared with the estimates of 1.10-1.48 cm- $\mathrm{y}^{-1}$ between 1982 and 2004 made by Dawson et al. (2010), they do fall within the range of $0.27-3.09 \mathrm{~cm} \mathrm{y}^{-1}$ presented in long-term monitoring programmes (Hutchinson, 1980; Richardson and Smith, 1977). It is also possible to make a 'back of the envelope' estimation of the time until SOC exhaustion in the region under current management and cropping rotations, from our estimated C stocks (Table 4) and current gaseous $\mathrm{CO}_{2}$ loss rates (Table 2). The most recent definition of Histosols in emissions inventorying (IPCC, 2006) gives a minimum threshold of $11.6 \%$ SOC in more than half of the top $80 \mathrm{~cm}$ soil. SOC exhaustion might therefore be thought of as the point at which the soil can no longer be defined as a Histosol, through continual incorporation of SOM from the underlying soil layers into the upper cultivated later (Couwenberg and Hooijer, 2013), and 
subsequent depletion to organo-mineral then mineral soil status. At our sites, SOC\% falls below the $11.6 \%$ threshold at $40 \mathrm{~cm}, 70 \mathrm{~cm}$ and $90 \mathrm{~cm}$ depths for the $\mathrm{SOC}_{\mathrm{LOW}}, \mathrm{SOC}_{\mathrm{MED}}$ and $\mathrm{SOC}_{\mathrm{HIGH}}$ sites respectively (Table 4). Dividing the remaining soil C stock within these profile sections by the current annual $\mathrm{CO}_{2}$ emission from these sites allows for between c. $80-160$ years before SOC depletion (assuming an average $1 \mathrm{~m}$ soil depth across the region; Dawson et al., 2010). However it should be noted that this estimate does not account for inputs of crop residues and plug plant compost which may partially restore a small quantity of OM to the soil each year. Conversely, allowing for losses via other routes (wind and water erosion, leaching of DOC, crop adherence, etc.), inter-annual variation in $\mathrm{CO}_{2}$ emissions and crop and soil management, and the commonly observed decline in soil quality as the soil profile is depleted and underlying mineral material becomes incorporated into the peat substrate (e.g. Hooijer et al., 2012; Kasimir-Klemedtsson et al., 1997), this may be an optimistic estimate. Taking into account the need for increasing fertiliser application and tillage rates to maintain crop quality as soil quality declines over time, the continuing commercial viability of intensively cultivated Histosols of 1-2 m depth may be as little as 50 years.

During SOM mineralization processes, depletion of soil $\mathrm{C}$ is also accompanied by $\mathrm{N}$ loss, calculated at our study sites as c. 250 to $625 \mathrm{~kg} \mathrm{~N} \mathrm{ha}^{-1} \mathrm{y}^{-1}$ (Section 4.2). While fluxes of gaseous $\mathrm{N}_{2} \mathrm{O}$ to the atmosphere merit attention for mitigation in their own right, the small proportion of theoretical $\mathrm{N}$ loss at our sites as gaseous $\mathrm{N}_{2} \mathrm{O}$ emissions suggests the potential for substantial losses via additional routes not accounted for in this study, which represent further potential sources of environmental pollution and commercial costs. Reliable estimates of $\mathrm{N}$ losses via leaching and erosion from arable peat soils are scarce, and studies accounting for losses from peat adherence to crops are unknown (e.g. Evans et al., 2011). Mulholland et al. (2008) estimated that $20-25 \%$ of all $\mathrm{N}$ added to terrestrial ecosystems may be lost via rivers, but the proportion of $\mathrm{N}$ lost to waterways that is eventually transformed to indirect 
$\mathrm{N}_{2} \mathrm{O}$ emission is subject to a great deal of uncertainty (IPCC, 2007). Drainage channels may account for the majority of indirect arable $\mathrm{N}_{2} \mathrm{O}$ emissions, with a recent study of a catchment in East Anglia comprising mineral and peat soils, estimating that $86 \%$ of indirect $\mathrm{N}_{2} \mathrm{O}$ emissions originated from drainage channels (Outram and Hiscock, 2012). Applying our top soil C:N ratios (Table 4) to estimated peak soil C losses from wind erosion in the East of England (> $3 \mathrm{t} \mathrm{ha}^{-1} \mathrm{y}^{-1}$; Dawson and Smith, 2007) places wind-eroded N at c. $180-210 \mathrm{tha}^{-1} \mathrm{y}^{-}$ ${ }^{1}$. Each of these losses exhibit 'downstream' effects resulting from soil nutrient loss, water and air pollution, impacting on aquatic and terrestrial ecosystems and human health (e.g. Berglund and Berglund, 2015; Parish et al., 2008).

\subsection{Conclusions}

The results of this study suggest that the default IPCC (2000) EFs for annual $\mathrm{N}_{2} \mathrm{O}$ emissions for cultivated Histosols may underestimate fluxes from intensively produced vegetable cropping systems, while $\mathrm{CO}_{2}$ and $\mathrm{CH}_{4}$ emissions were within a comparable range to the IPCC default values. When calculating losses of soil organic matter via GHG efflux to the atmosphere, attention should be given to the variability in emissions experienced under different weather conditions and different cropping regimes, which both vary inter-annually and geographically. Using longer-term studies as the basis of Tier 2 emissions estimates may aid progress towards more accurate quantification of the variability between sites and years. The lower rates of GHG emission-related soil loss estimated from soils of lower organic matter content present a potential problem for policy-makers in incentivising growers to reduce GHG emissions from peat soils of higher organic matter content, although assessing the time-frame of negative commercial impacts of declining soil quality may aid the mitigation process. Determining suitable cost-neutral or cost-negative mitigation measures, 
and investigating grower motivation to implement changes to farming practices or alternative land uses which reduce net emissions, merit further attention.

\section{Acknowledgements}

This work was funded by the European Union's Knowledge Economy Skills Scholarships programme, in partnership with Footprints4Food. The authors are grateful to technical and academic colleagues who provided advice and assistance with practical work. 


\section{References}

Alm, J., Shurpail, N.J., Tuittila, E.-S., Laurila, T., Maljanen, M., Saarnio, S., Minkkinen, K., 2007. Methods for determining emission factors for the use of peat and peatlands - flux measurements and modelling. Boreal Environ. Res. 12, 85-100.

Berglund, Ö., Berglund, K., 2015. Organic matter loss from cultivated peat soils in Sweden. Geophys. Res. Abstr. 17.

Boon, A., Robinson, J.S., Chadwick, D.R., Cardenas, L.M., 2014. Effect of cattle urine addition on the surface emissions and subsurface concentrations of greenhouse gases in a UK peat grassland. Agric. Ecosyst. Environ. 186, 23-32. http://dx.doi.org/10.1016/j.agee.2014.01.008

Brown, L., Syed, B., Jarvis, S.C., Sneath, R.W., Phillips, V.R., Goulding, K.W.T., Li, C. 2002. Development and application of a mechanistic model to estimate emission of nitrous oxide from UK agriculture. Atmos. Environ. 36, 917-928. http://dx.doi.org/10.1016/S1352-2310(01)00512-X

Burden, A., Garbutt, R.A., Evans, C.D., Jones, D.L., Cooper, D. M., 2013. Carbon sequestration and biogeochemical cycling in a saltmarsh subject to coastal managed realignment. Estuar. Coast. Shelf Sci. 120, 12-20. doi:10.1016/j.ecss.2013.01.014

Cannell, M.G.R., Milne, R., Hargreaves, K.J., Brown, T.A.W., Cruickshank, M.M., Bradley, R.I., Spencer, T., Hope, D., Billett, M.F., Adger, W.N., Subak, S., 1999. National inventories of terrestrial carbon sources and sinks: The U.K. experience. Clim. Change 42, 505-530. doi: 10.1023/A:1005425807434

Chen, D., Li, Y., Grace, P., Mosier, A.R., 2008. $\mathrm{N}_{2} \mathrm{O}$ emissions from agricultural lands: a synthesis of simulation approaches. Plant Soil 309, 169-189. doi:10.1007/s11104-0089634-0 
Couwenberg, J., Hooijer, A. 2013. Towards robust subsidence-based soil carbon emission factors for peat soils in south-east Asia, with special reference to oil palm plantations. Mires Peat 12, 1-13.

http://www.mires-and-peat.net/pages/volumes/map12/map1201.php

Dawson, J.J.C., Smith, P., 2007. Carbon losses from soil and its consequences for land-use management. Sci. Total Environ. 382, 165-190. doi:10.1016/j.scitotenv.2007.03.023

Dawson, Q., Kechavarzi, C., Leeds-Harrison, P.B., Burton, R.G.O., 2010. Subsidence and degradation of agricultural peatlands in the Fenlands of Norfolk, UK. Geoderma 154, 181-187. doi:10.1016/j.geoderma.2009.09.017

De Klein, C.A.M., Harvey, M.J. 2013. Nitrous oxide chamber methodology guidelines. Ministry for Primary Industries, Wellington, NZ. ISBN 978-0-478-40585-9 (online).

Doran, J. W., Jones, A. J. (Eds.)., 1996. Methods for assessing soil quality. SSSA Special Publication No. 49. Soil Science Society of America, Inc. Madison, WI.

EEA, 2015. Annual European Union greenhouse gas inventory 1990-2013 and inventory report 2015. Submission to the UNFCCC Secretariat, 27 November 2015. Technical report No 19/2015. European Environment Agency, Copenhagen. http://www.eea.europa.eu//publications/european-union-greenhouse-gas-inventory2015

Elder, J.W., Lal, R., 2008. Tillage effects on gaseous emissions from an intensively farmed organic soil in North Central Ohio. Soil Tillage Res. 98, 45-55. doi:10.1016/j.still.2007.10.003

Elsgaard, L., Görres, C.-M., Hoffmann, C.C., Blicher-Mathiesen, G., Schelde, K., Petersen, S.O., 2012. Net ecosystem exchange of $\mathrm{CO}_{2}$ and carbon balance for eight temperate organic soils under agricultural management. Agric. Ecosyst. Environ. 162, 52-67. http://dx.doi.org/10.1016/j.agee.2012.09.001 
Estop-Aragonés, C., Blodau, C., 2012. Effects of experimental drying intensity and duration on respiration and methane production recovery in fen peat incubations. Soil Biol. Biochem. 47, 1-9. doi:10.1016/j.soilbio.2011.12.008

Evans, C., Worrall, F., Holden, J., Chapman, P., Smith, P., Artz, R., 2011. A programme to address evidence gaps in greenhouse gas and carbon fluxes from UK peatlands. $52 \mathrm{pp}$. JNCC, Peterborough. http://jncc.defra.gov.uk/pdf/jncc443_web.pdf

Ewing, J. M., Vepraskas, M. J., 2006. Estimating primary and secondary subsidence in an organic soil 15, 20 and 30 years after drainage. Wetlands 26 (1), 119-130. doi:10.1672/0277-5212(2006)26[119:EPASSI]2.0.CO;2

Field, A., 2005. Discovering statistics using SPSS, second ed. Sage Publications, Ltd., London.

Flessa, H., Wild, U., Klemisch, M., Pfadenhauer, J., 1998. Nitrous oxide and methane fluxes from organic soils under agriculture. Eur. J. Soil Sci. 49, 327-335. doi:10.1046/j.13652389.1998.00156.x

Ford, H., Garbutt, A., Jones, L., Jones, D.L., 2012. Methane, carbon dioxide and nitrous oxide fluxes from a temperate salt marsh: grazing management does not alter global warming potential. Estuar. Coast. Shelf Sci. 113, 182-191. http://dx.doi.org/10.1016/j.ecss.2012.08.002

Giltrap, D.L., Li, C., Saggar, S., 2010. DNDC: A process-based model of greenhouse gas fluxes from agricultural soils. Agric. Ecosyst. Environ. 136, 292-300. doi:10.1016/j.agee.2009.06.014

Hatala, J.A., Detto, M., Sonnentag, O., Deverel, S.J., Verfaillie, J., Baldocchi, D.D., 2012. Greenhouse gas $\left(\mathrm{CO}_{2}, \mathrm{CH}_{4}, \mathrm{H}_{2} \mathrm{O}\right)$ fluxes from drained and flooded agricultural peatlands in the Sacramento-San Joaquin Delta Agric. Ecosyst. Environ. 150, 1-18. doi:10.1016/j.agee.2012.01.009 
Hooijer, A., Page, S., Jauhiainen, J., Lee, W.A., Lu, X.X., Idris, A., Anshari, G., 2012. Subsidence and carbon loss in drained tropical peatlands. Biogeosci. 9, 1053-1071. doi:10.5194/bg-9-1053-2012

Hutchinson, J. N., 1980. The record of peat wastage in the East Anglian Fenlands at Holme Post, 1848-1978 A. D. J. Ecol. 68, 229-249. http://www.jstor.org/stable/2259253

IPCC, 2000. Good practice guidance and uncertainty management in national greenhouse gas inventories. IPCC, Geneva, Switzerland. http://www.ipccnggip.iges.or.jp/public/gp/english/

IPCC, 2006. 2006 IPCC Guidelines for National Greenhouse Gas Inventories, Prepared by the National Greenhouse Gas Inventories Programme, Eggleston H.S., Buendia L., Miwa K., Ngara T. and Tanabe K. (Eds.), IGES, Japan. http://www.ipccnggip.iges.or.jp/public/2006gl/vol4.html

IPCC. 2007. Climate Change 2007: Synthesis Report. Contribution of Working Groups I, II, and III to the Fourth Assessment Report of the Intergovernmental Panel on Climate Change. [Core Writing Team, Pachauri, R. K., and Reisinger, A. (eds.)]. IPCC, Geneva, Switzerland, 104 pp. https://www.ipcc.ch/pdf/assessment-report/ar4/syr/ar4_syr.pdf IPCC, 2014. 2013 Supplement to the 2006 IPCC Guidelines for National Greenhouse Gas Inventories: Wetlands. Hiraishi, T., Krug, T., Tanabe, K., Srivastava, N., Baasansuren, J., Fukuda, M. and Troxler, T.G. (Eds.), IPCC, Switzerland. http://www.ipccnggip.iges.or.jp/public/wetlands/

Kasimir-Klemedtsson, Á., Klemedtsson, L., Berglund, K., Martikainen, P., Silvola, J., Oenema, O., 1997. Greenhouse gas emissions from farmer organic soils: a review. Soil Use Manage. 13, 245-250. doi:10.1111/j.1475-2743.1997.tb00595.x 
Kechavarzi, C., Dawson, Q., Leeds-Harrison, P.B., Szatyłowicz, J., Gnatowski, T., 2007. Water-table management in lowland UK peat soils and its potential impact on $\mathrm{CO}_{2}$ emission. Soil Use Manage. 23, 359-367. doi:10.1111/j.1475-2743.2007.00125.x

Koerber, G. R., Hill, P. W., Edwards-Jones, G., Jones, D. L., 2010. Estimating the component of soil respiration not dependent on living plant roots: Comparison of the indirect yintercept regression approach and direct bare plot approach. Soil Biol. Biochem. 42, 1835-1841. doi:10.1016/j.soilbio.2010.06.024

Kuzyakov, Y., Friedel, J.K., Stahr, K. 2000. Review of mechanisms and quantification of priming effects. Soil Biol. Biochem. 32, 1485-1498. http://dx.doi.org/10.1016/S00380717(00)00084-5

Kuzyakov, Y. 2010. Priming effects: Interactions between living and dead organic matter. Soil Biol. Biochem. 42, 1363-1371. doi:10.1016/j.soilbio.2010.04.003

Le Mer, J., Roger, P., 2001. Production, oxidation, emission and consumption of methane by soils: A review. Eur. J. Soil Biol. 37, 25-50. doi:10.1016/S1164-5563(01)01067-6

Leifeld, J., Müller, M., Fuhrer, J., 2011. Peatland subsidence and carbon loss from drained temperate fens. Soil Use Manage. 27, 170-176. doi:10.1111/j.1475-2743.2011.00327.x

Leip, A., 2010. Quantitative quality assessment of the greenhouse gas inventory for agriculture in Europe. Clim. Change 103, 245-261. doi:10.1007/s10584-010-9915-5

Levy, P.E., Gray, A., Leeson, S.R., Gaiawyn, J., Kelly, M.P.C., Cooper, M.D.A., Dinsmore, K.J., Jones, S.K., Sheppard, L.J., 2011. Quantification of uncertainty in trace gas fluxes measured by the static chamber method. Eur. J. Soil Sci. 62, 811-821.

doi:10.1111/j.1365-2389.2011.01403.x

Li, C., 2007. Quantifying greenhouse gas emissions from soils: Scientific basis and modeling approach. Soil Sci. Plant Nutr. 53, 344-352. doi:10.1111/j.1747-0765.2007.00133.x 
Limpens, J., Berendse, F., Blodau, C., Canadell, J.G., Freeman, C., Holden, J., Roulet, N., Rydin, H., Schaepman-Strub, G., 2008. Peatlands and the carbon cycle: from local processes to global implications - a synthesis. Biogeosci. Discuss. 5, 1379-1419. doi:10.5194/bg-5-1475-2008

Maljanen, M., Martikainen, P.J., Walden, J., Silvola, J., 2001. $\mathrm{CO}_{2}$ exchange in an organic field growing barley or grass in eastern Finland. Glob. Change Biol. 7, 679-692. doi:10.1111/j.1365-2486.2001.00437.x

Maljanen, M., Martikainen, P.J., Aaltonen, H., Silvola, J., 2002. Short-term variation in fluxes carbon dioxide, nitrous oxide and methane in cultivated and forested organic boreal soils. Soil Biol. Biochem. 34, 577-584. doi:10.1016/S0038-0717(01)00213-9

Maljanen, M., Komulainen, V.-M., Hytönen, J., Martikainen, P.J., Laine, J., 2004. Carbon dioxide, nitrous oxide and methane dynamics in boreal organic agricultural soils with different soil characteristics. Soil Biol. Biochem. 36, 1801-1808. doi:10.1016/j.soilbio.2004.05.003

Miranda, K.M., Espey, M.G., Wink, D.A., 2001. A rapid, simple spectrophotometric method for simultaneous detection of nitrate and nitrite. Nitric oxide 5, 62-71. doi:10.1006/niox.2000.0319

Mulholland, P.J., A., Helton, M.A., Poole, G.C., Hall, R.O., Hamilton, S.K., Peterson, B.J., Tank, J.L., Ashkenas, L.R., Cooper, L.W., Dahm, C.N., Dodds, W.K., Findlay, S.E.G., Gregory, S.V., Grimm, N.B., Johnson, S.L., McDowell, W.H., Meyer, J.L., Valett, H.M., Webster, J.R., Arango, C.P., Beaulieu, J.J., Bernot, M.J., Burgin, A.J., Crenshaw, C.L., Johnson, L.T., Niederlehner, B.R., O'Brien, J.M., Potter, J.D., Sheibley, R.W., Sobota, D.J., Thomas, S.M., 2008. Stream denitrification across biomes and its response to anthropogenic nitrate loading. Nature 452, 202-206. doi:10.1038/nature06686 
Mulvaney, R.L., 1996. Nitrogen - inorganic forms, in: Sparks, D.L. (Ed.), Methods of Soil Analysis, Part 3: Chemical Methods. SSSA, Madison, WI, USA, pp. 1123-1184.

Outram, F.N., Hiscock, K.M., 2012. Indirect nitrous oxide emissions from surface water bodies in a lowland arable catchment: a significant contributor to agricultural greenhouse gas budgets? Environ. Sci. Technol. 46, 8156-8163. dx.doi.org/10.1021/es3012244

Parish, F., Sirin, A., Charman, D., Joosten, H., Minayeva, T., Silvius, M., Stringer, L. (Eds.), 2008. Assessment on peatlands, biodiversity and climate change: main report. Global Environment Centre, Kuala Lumpur and Wetlands International, Wageningen, Netherlands. http://gec.org.my/index.cfm?\&menuid=48

Parkin, T.B., Kaspar, T.C., 2003. Temperature controls on diurnal carbon dioxide flux: implications for estimating soil carbon loss. Soil Sci. Soc. Am. J. 67, 1763-1772. doi:10.2136/sssaj2003.1763

Regina, K., Syväsalo, E., Hannukkala, A., Esala, M., 2004. Fluxes of $\mathrm{N}_{2} \mathrm{O}$ from farmed peat soils in Finland. Eur. J. Soil Sci. 55, 591-599. doi:10.1111/j.1365-2389.2004.00622.x

Richardson, S.J., Smith, J., 1977. Peat wastage in the East Anglian fens. J. Soil Sci. 28, 485489. doi:10.1111/j.1365-2389.1977.tb02256.x

Rochette, P., Tremblay, N., Fallon, E., Angers, D.A., Chantigny, M.H., MacDonald, J.D., Bertrand, N., Parent, L.-É., 2010. $\mathrm{N}_{2} \mathrm{O}$ emissions from an irrigated and non-irrigated organic soil in eastern Canada as influenced by N fertiliser addition. Eur. J. Soil Sci. 61, 186-196. doi:10.1111/j.1365-2389.2009.01222.x

Smith, P., Chapman, S.J., Scott, W.A., Black, H.I.J, Wattenbach, M., Milne, R., Campbell, C.D., Lilly, A., Ostle, N., Levy, P.E., Lumsdon, D.G., Millard, P., Towers, W., Zaehle S., Smith, J.U., 2007. Climate change cannot be entirely responsible for soil carbon loss 
observed in England and Wales, 1978-2003. Glob. Change Biol. 13, 2605-2609. doi:10.1111/j.1365-2486.2007.01458.x

Smith, P., Martino, D., Cai, Z., Gwary, D., Janzen, H., Kumar, P., McCarl, B., Ogle, S., O'Mara, F., Rice, C., Scholes, B., Sirotenko, O., Howden, M., McAllister, T., Pan, G., Romanenkov, V., Schneider, U., Towprayoon, S., Wattenbach, M., Smith, J., 2008. Greenhouse gas mitigation in agriculture. Philos. Trans. R. Soc. B: Biol. Sci. 363, 789813. doi:10.1098/rstb.2007.2184

Smith, J., Gottschalk, P., Bellarby, J., Chapman, S., Lilly, A., Towers, W., Bell, J., Coleman, K., Nayak, D., Richards, M., Hillier, J., Flynn, H., Wattenbach, M., Aitkenhead, M., Yeluripati, J., Farmer, J., Milne, R., Thomson, A., Evans, C., Whitmore, A., Falloon, P., Smith, P., 2010. Estimating changes in Scottish soil carbon stocks using ECOSSE. I. Model description and uncertainties. Clim. Res. 45, 179-182. doi:10.3354/cr00902

UK Met Office. 2014. UK Climate and weather statistics. http://www.metoffice.gov.uk/climate/uk/summaries/actualmonthly (accessed March 2014).

Waddington, J.M., Strack, M., Greenwood, M.J. 2010. Toward restoring the net carbon sink function of degraded peatlands: Short-term response in $\mathrm{CO}_{2}$ exchange to ecosystemscale restoration. J. Geophys. Res. 115, G01008. doi:10.1029/2009JG001090 Webb, N., Broomfield, M., Brown, P., Buys, G., Cardenas, L., Murrells, T., Pang, Y., Passant, N., Thistlethwaite, G., Watterson, J., Abbott, J., Champion, H., Choudrie, S., Coleman, C., Gilhespy, S., Gluckman, R., Goodwin, J., Henshall, P., Hobson, M., Levy, P., MacCarthy, J., Malcolm, H., Manning, A., Matthews, R., Miles, S., Misselbrook, T., Moxley, J., Pearson, B., Salisbury, E., Wartmann, S., Walker, C., 2014. UK Greenhouse Gas Inventory, 1990 to 2012: Annual Report for Submission under the Framework Convention on Climate Change. DECC, United Kingdom. 
https://www.gov.uk/government/uploads/system/uploads/attachment_data/file/310779/ UK_National_Inventory_Report_Main_1990-2012.pdf

Weslien, P., Rütting, T., Kasimir-Klemedtsson, Á., Klemedtsson, L., 2012. Carrot cropping on organic soil is a hotspot for nitrous oxide emissions. Nutr. Cycl. Agroecosys. 94, 249-253. doi:10.1007/s10705-012-9538-5

Worrall, F., Chapman, P., Holden, J., Evans, C., Artz, R., Smith, P., Grayson, R., 2011. A review of current evidence on carbon fluxes and greenhouse gas emissions from UK peatlands. JNCC, Peterborough, UK. http://jncc.defra.gov.uk/pdf/jncc442_webFinal.pdf

Ye, R., Espe, M.B., Linquist, B., Parikh, S.J., Doane, T.A., Horwath, W.R., 2016. A soil carbon proxy to predict $\mathrm{CH} 4$ and $\mathrm{N} 2 \mathrm{O}$ emissions from rewetted agricultural peatlands. Agric. Ecosyst. Environ. 220, 64-75. http://dx.doi.org/10.1016/j.agee.2016.01.008

York, E.H., 2012. Modelling greenhouse gas emissions for the UK and overseas food production. PhD thesis, Bangor University, Bangor, UK. 

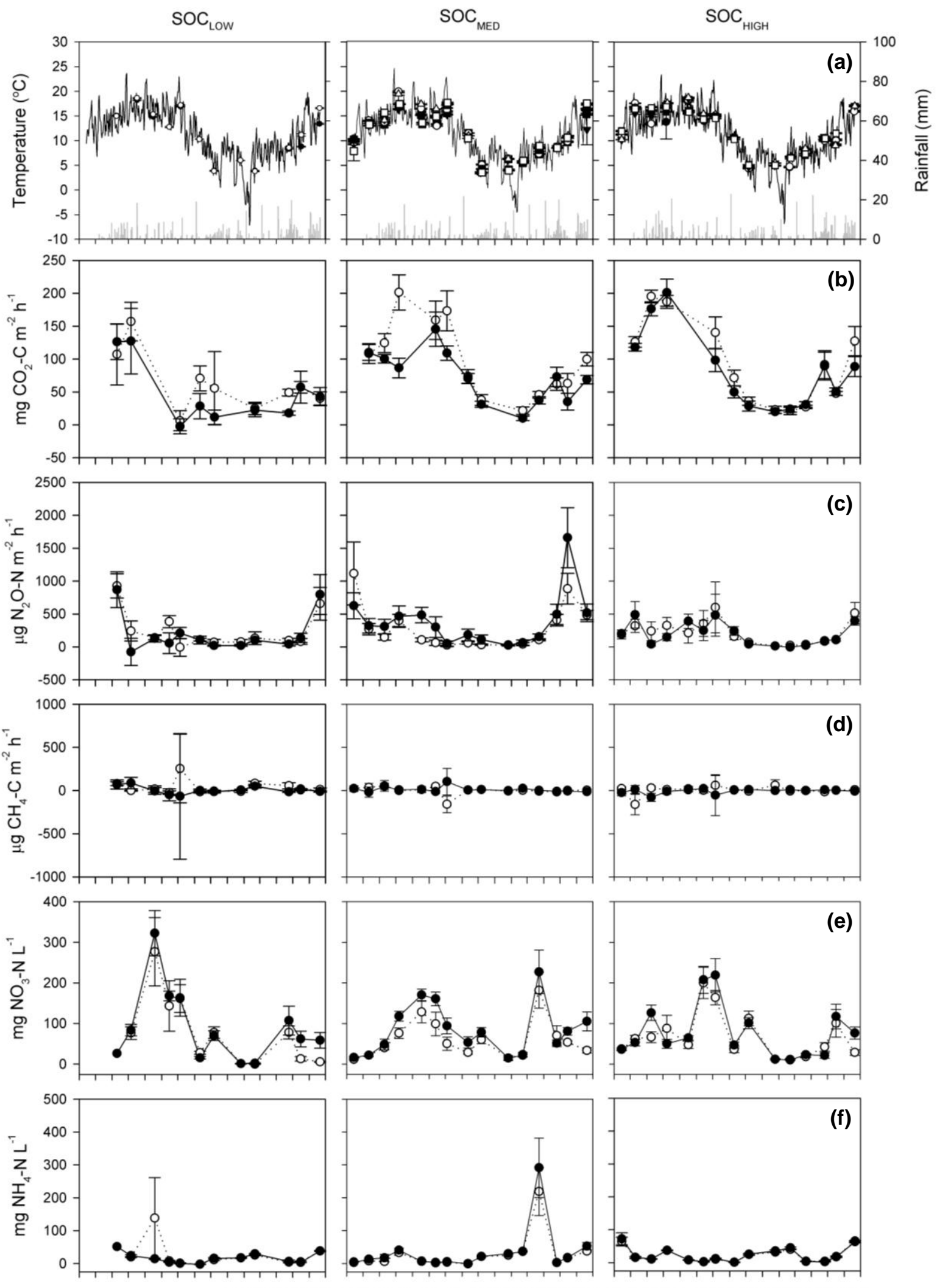

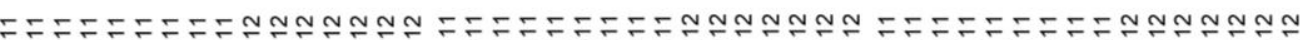

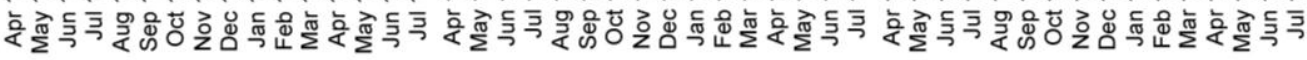
Date Date

Figure 1 
Daily rainfall, air temperature and soil temperature (a); fluxes of $\mathrm{CO}_{2}(\mathrm{~b}), \mathrm{N}_{2} \mathrm{O}$ (c), and $\mathrm{CH}_{4}$ (d); and soil $\mathrm{NO}_{3}{ }^{-}$(e) and $\mathrm{NH}_{4}{ }^{+}$(f); $14^{\text {th }}$ April 2011 to $21^{\text {st }}$ June 2012: cropped and bare soils at $\mathrm{SOC}_{\mathrm{LOW}}$ site ( 20\% SOM content), $\mathrm{SOC}_{\mathrm{MED}}$ site ( $\sim 35 \%$ SOM content), and $\mathrm{SOC}_{\mathrm{HIGH}}$ site $(\sim 70 \%$ SOM content $)$.

In panel (a), MIDAS mean air temperature $\left({ }^{\circ} \mathrm{C}\right)$ is denoted by a solid black line, rainfall $(\mathrm{mm})$ by grey bars; and mean soil temperature by solid black circles (cropped soil, fields 1,4 and 7), open circles (bare soil, fields 1, 4 and 7), black triangles (cropped soil, fields 2 and 5), open triangles (bare soil, fields 2 and 5), black squares (cropped soil, fields 3 and 6), and open squares (bare soil, fields 3 and 6). In panels (b) to (f), cropped soil values are denoted by a black circle and bare soil values by an open circle. 


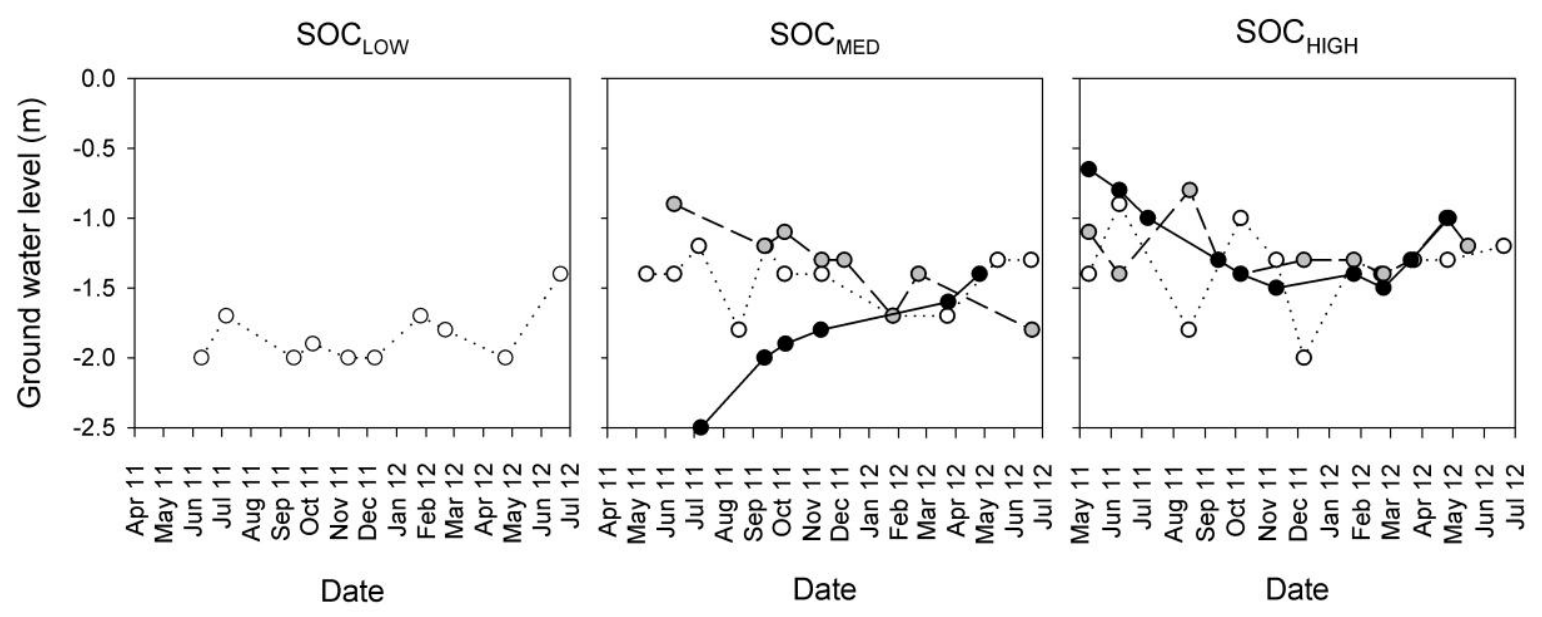

\section{Figure 2}

Ground water levels measured at drainage ditches bordering study fields; $14^{\text {th }}$ April 2011 to

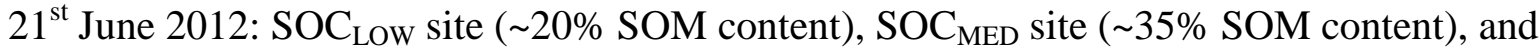
$\mathrm{SOC}_{\mathrm{HIGH}}$ site $(\sim 70 \%$ SOM content $)$.

Separate fields are denoted: at $\mathrm{SOC}_{\mathrm{LOw}}$ site, field 1 by open circles; at $\mathrm{SOC}_{\mathrm{MED}}$ and $\mathrm{SOC}_{\mathrm{HIGH}}$ sites, field 1 by open circles, field 2 by grey circles, and field 3 by black circles. 


\section{Table 1}

Summary of the significant linear correlations between measured environmental variables and emissions of $\mathrm{CO}_{2}, \mathrm{~N}_{2} \mathrm{O}$ and $\mathrm{CH}_{4}$ in intensively managed horticultural soils.

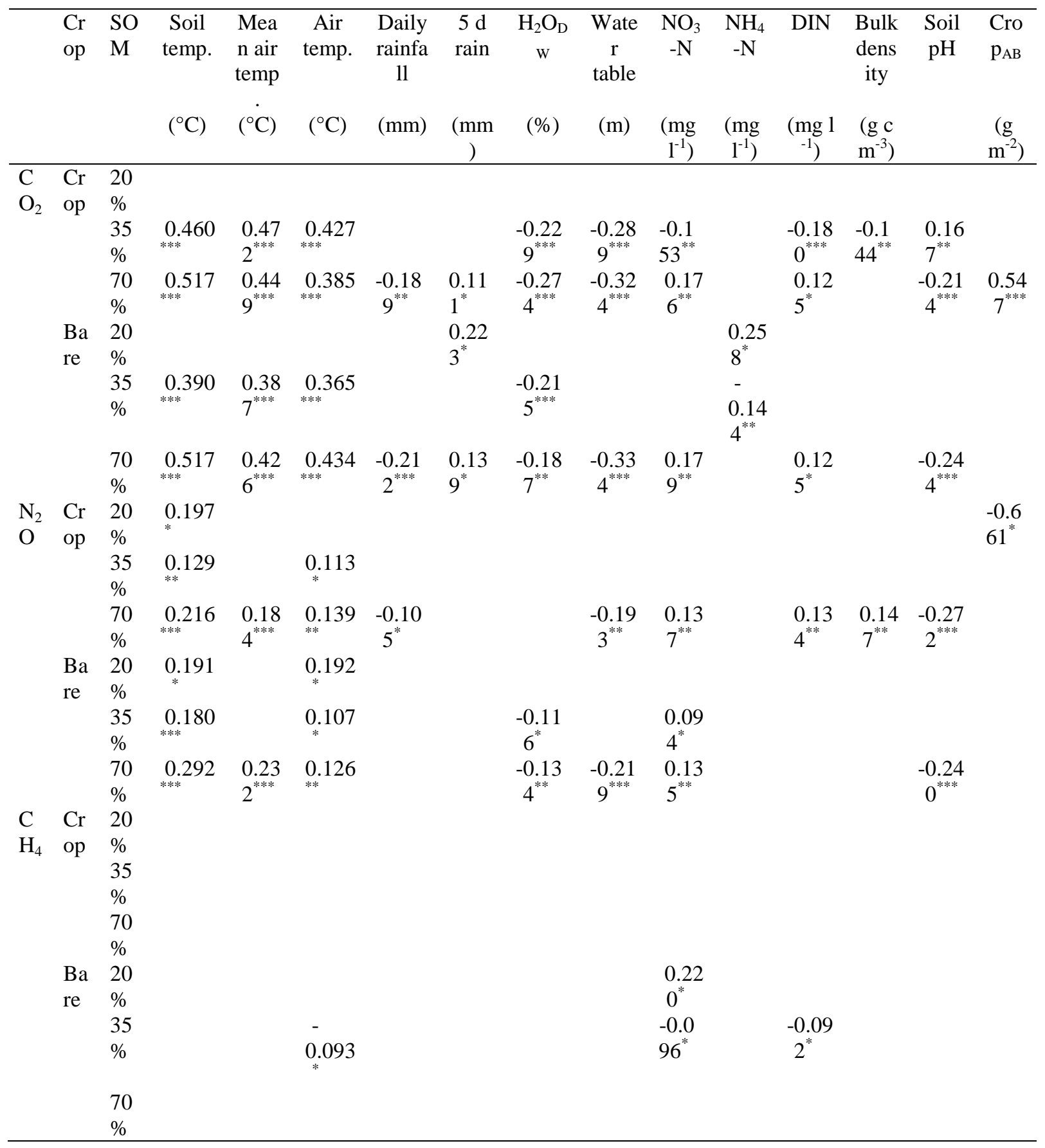

Values are presented as Kendall's tau statistic $(\tau)$, with significance levels presented as ${ }^{*}(p<0.05),{ }^{* *}(p<0.01)$, or ${ }^{* * *}(p<0.001)$. Environmental variables presented are: Soil temp. (soil temperature); Mean air temp. (mean MIDAS daily air temperature); Air temp. (measured air temperature); Daily rainfall (cumulative MIDAS daily rainfall); $5 \mathrm{~d}$ rain 
(cumulative MIDAS 5-day rainfall); $\mathrm{H}_{2} \mathrm{O}_{\text {DW }}$ (Gravimetric soil water content, \% of dry weight); Water table (water table depth); $\mathrm{NO}_{3}-\mathrm{N}$ (soil extractable nitrate); $\mathrm{NH}_{4}-\mathrm{N}$ (soil extractable ammonium); DIN (soil extractable nitrate + ammonium); Bulk density (topsoil bulk density); Soil $\mathrm{pH}$ (soil $\mathrm{pH}$ ); and $\mathrm{Crop}_{\mathrm{AB}}$ (Crop aerial biomass). 


\section{Table 2}

Cumulative annual fluxes of $\mathrm{CO}_{2}, \mathrm{~N}_{2} \mathrm{O}$ and $\mathrm{CH}_{4}$, and total cumulative greenhouse gas emissions $\left(G W P_{100}\right)$ for cropped and bare soils of contrasting organic matter status under horticultural production. The $\mathrm{SOC}_{\mathrm{LOW}}, \mathrm{SOC}_{\mathrm{MED}}$, and $\mathrm{SOC}_{\mathrm{HIGH}}$ categories correspond to soil organic matter contents of $\sim 20 \%, \sim 35 \%$ and $\sim 70 \%$ respectively. Values represent means \pm SEM.

\begin{tabular}{|c|c|c|c|c|c|c|c|c|}
\hline \multirow[t]{3}{*}{ Organic matter status } & \multicolumn{8}{|c|}{ Cumulative annual fluxes $\left(\mathrm{t} \mathrm{CO}_{2}-\mathrm{e} \mathrm{ha}^{-1} \mathrm{y}^{-1}\right)$} \\
\hline & \multicolumn{4}{|c|}{ Cropped soil } & \multicolumn{4}{|c|}{ Bare soil } \\
\hline & $\mathrm{CO}_{2}$ & $\mathrm{~N}_{2} \mathrm{O}$ & $\mathrm{CH}_{4}$ & $\mathrm{GWP}_{100}$ & $\mathrm{CO}_{2}$ & $\mathrm{~N}_{2} \mathrm{O}$ & $\mathrm{CH}_{4}$ & $\mathrm{GWP}_{100}$ \\
\hline $\mathrm{SOC}_{\text {LOW }}$ & $19.2 \pm 2.7$ & $6.90 \pm 2.10$ & $-0.01 \pm 0.09$ & $26.1 \pm 3.4$ & $13.0 \pm 2.4$ & $4.97 \pm 0.74$ & $-0.02 \pm 0.08$ & $17.9 \pm 3.0$ \\
\hline $\mathrm{SOC}_{\mathrm{MED}}$ & $30.9 \pm 2.5$ & $7.93 \pm 0.78$ & $0.04 \pm 0.02$ & $38.8 \pm 2.4$ & $21.5 \pm 1.1$ & $13.9 \pm 1.91$ & $0.00 \pm 0.01$ & $35.4 \pm 2.0$ \\
\hline $\mathrm{SOC}_{\mathrm{HIGH}}$ & $28.3 \pm 2.3$ & $7.90 \pm 2.23$ & $0.01 \pm 0.04$ & $36.2 \pm 2.1$ & $26.0 \pm 2.5$ & $6.66 \pm 1.49$ & $0.04 \pm 0.05$ & $32.7 \pm 2.3$ \\
\hline
\end{tabular}

$G W P_{100}$, Global warming potential over 100 years of combined $\mathrm{CO}_{2}, \mathrm{~N}_{2} \mathrm{O}$ and $\mathrm{CH}_{4}$ flux. 


\section{Table 3}

Two-way analysis of variance of the fixed effects of SOM\% and cropping (cropped vs. bare soils) on annual cumulative $G W P_{100}$, and $\mathrm{CO}_{2}$ and $\mathrm{N}_{2} \mathrm{O}$ emissions (10 ${ }^{\text {th }}$ Jun 2011 to $9^{\text {th }}$ Jun 2012).

\begin{tabular}{|c|c|c|c|}
\hline \multicolumn{4}{|l|}{ (a) $G W P_{100}$} \\
\hline Source & $\mathrm{df}$ & F-value & $\mathrm{P}$-value \\
\hline SOM\% & 2 & 12.254 & $<0.001$ \\
\hline Cropping & 1 & 4.882 & 0.031 \\
\hline SOM $\% \times$ Cropping & 2 & 0.352 & 0.705 \\
\hline \multicolumn{4}{|l|}{ (b) $\mathrm{CO}_{2}{ }^{\mathrm{a}}$} \\
\hline Source & $\mathrm{df}$ & F-value & P-value \\
\hline SOM\% & 2 & 8.857 & $<0.001$ \\
\hline Cropping & 1 & 8.395 & 0.005 \\
\hline SOM\% $\times$ Cropping & 2 & 1.275 & 0.286 \\
\hline \multicolumn{4}{|l|}{ (c) $\mathrm{N}_{2} \mathrm{O}^{\mathrm{a}}$} \\
\hline Source & df & F-value & P-value \\
\hline SOM\% & 2 & 5.601 & 0.006 \\
\hline Cropping & 1 & 0.264 & 0.609 \\
\hline SOM $\% \times$ Cropping & 2 & 2.485 & 0.091 \\
\hline
\end{tabular}

${ }^{a}$ Performed on square-root transformed emissions values.

\section{Table 4}


Estimated $\mathrm{C}$ and $\mathrm{N}$ stocks to $1 \mathrm{~m}$ depth at intensively managed horticultural soils of contrasting organic matter status. Values represent means \pm SEM.

Organic matter status

\begin{tabular}{|c|c|c|c|c|c|c|c|c|c|c|c|c|c|c|c|}
\hline \multirow{2}{*}{$\begin{array}{l}\text { Soil } \\
\text { depth } \\
\text { (cm) }\end{array}$} & \multicolumn{6}{|c|}{$\mathrm{SOC}_{\text {LOW }}$} & \multicolumn{4}{|c|}{$\mathrm{SOC}_{\mathrm{MED}}$} & \multicolumn{5}{|c|}{$\mathrm{SOC}_{\mathrm{HIGH}}$} \\
\hline & $\begin{array}{c}\text { Bulk } \\
\text { density } \\
\left(\mathrm{g} \mathrm{cm}^{-3}\right)\end{array}$ & $\begin{array}{c}\text { Total C } \\
(\%)\end{array}$ & $\begin{array}{l}\text { C stock } \\
\left(\mathrm{t} \mathrm{ha}^{-1}\right)\end{array}$ & $\begin{array}{c}\text { Total N } \\
(\%)\end{array}$ & $\begin{array}{l}\text { N stock } \\
\left(\mathrm{t} \mathrm{ha}^{-1}\right)\end{array}$ & $\begin{array}{c}\text { Bulk } \\
\text { density } \\
\left(\mathrm{g} \mathrm{cm}^{-3}\right)\end{array}$ & $\begin{array}{c}\text { Total C } \\
(\%)\end{array}$ & $\begin{array}{l}\text { C stock } \\
\left(\mathrm{t} \mathrm{ha}^{-1}\right)\end{array}$ & $\begin{array}{c}\text { Total N } \\
(\%)\end{array}$ & $\begin{array}{l}\text { N stock } \\
\left(\mathrm{t} \mathrm{ha}^{-1}\right)\end{array}$ & $\begin{array}{c}\text { Bulk } \\
\text { density } \\
\left(\mathrm{g} \mathrm{cm}^{-3}\right)\end{array}$ & $\begin{array}{c}\text { Total C } \\
(\%)\end{array}$ & $\begin{array}{l}\text { C stock } \\
\left(\mathrm{t} \mathrm{ha}^{-1}\right)\end{array}$ & $\begin{array}{c}\text { Total N } \\
(\%)\end{array}$ & $\begin{array}{l}\text { N stock } \\
\left(\mathrm{t} \mathrm{ha}^{-1}\right)\end{array}$ \\
\hline $0-10$ & $\begin{array}{c}0.76 \pm \\
0.03\end{array}$ & $\begin{array}{c}19.1 \pm \\
0.4\end{array}$ & $\begin{array}{c}145.1 \pm \\
3.1\end{array}$ & $\begin{array}{l}1.3 \pm \\
0.02\end{array}$ & $\begin{array}{c}10.1 \pm \\
0.2\end{array}$ & $\begin{array}{c}0.39 \pm \\
0.01\end{array}$ & $\begin{array}{c}33.7 \pm \\
0.5\end{array}$ & $\begin{array}{c}130.7 \pm \\
1.5\end{array}$ & $\begin{array}{l}2.0 \pm \\
0.03\end{array}$ & $7.9 \pm 0.1$ & $\begin{array}{c}0.35 \pm \\
0.02\end{array}$ & $\begin{array}{c}38.8 \pm \\
4.2\end{array}$ & $\begin{array}{c}137.9 \pm \\
19.6\end{array}$ & $\begin{array}{c}2.4 \pm \\
0.29\end{array}$ & $8.7 \pm 1.2$ \\
\hline $10-20$ & $\begin{array}{c}0.83 \pm \\
0.07\end{array}$ & $\begin{array}{l}17.9 \pm \\
2.3\end{array}$ & $\begin{array}{c}145.1 \pm \\
8.3\end{array}$ & $\begin{array}{l}1.3 \pm \\
0.15\end{array}$ & $\begin{array}{c}10.5 \pm \\
0.3\end{array}$ & $\begin{array}{l}0.37 \pm \\
0.002\end{array}$ & $\begin{array}{c}33.2 \pm \\
0.4\end{array}$ & $\begin{array}{c}123.9 \pm \\
1.4\end{array}$ & $\begin{array}{l}2.0 \pm \\
0.03\end{array}$ & $7.3 \pm 0.1$ & $\begin{array}{c}0.37 \pm \\
0.02\end{array}$ & $\begin{array}{c}31.0 \pm \\
12.8\end{array}$ & $\begin{array}{c}110.3 \pm \\
44.5\end{array}$ & $\begin{array}{l}1.9 \pm \\
0.88\end{array}$ & $6.5 \pm 3.1$ \\
\hline $20-30$ & $\begin{array}{c}0.76 \pm \\
0.01\end{array}$ & $\begin{array}{c}18.9 \pm \\
1.4\end{array}$ & $\begin{array}{c}143.0 \pm \\
9.1\end{array}$ & $\begin{array}{l}1.4 \pm \\
0.10\end{array}$ & $\begin{array}{c}10.4 \pm \\
0.7\end{array}$ & $\begin{array}{c}0.39 \pm \\
0.03\end{array}$ & $\begin{array}{c}44.0 \pm \\
9.0\end{array}$ & $\begin{array}{c}176.5 \pm \\
46.0\end{array}$ & $\begin{array}{l}2.6 \pm \\
0.62\end{array}$ & $\begin{array}{c}10.7 \pm \\
3.2\end{array}$ & $\begin{array}{c}0.35 \pm \\
0.05\end{array}$ & $\begin{array}{c}42.8 \pm \\
2.2\end{array}$ & $\begin{array}{c}150.2 \pm \\
22.1\end{array}$ & $\begin{array}{l}2.7 \pm \\
0.05\end{array}$ & $9.6 \pm 1.5$ \\
\hline $30-40$ & $\begin{array}{l}0.85 \pm \\
0.05\end{array}$ & $\begin{array}{l}16.7 \pm \\
2.6\end{array}$ & $\begin{array}{c}139.9 \pm \\
15.5\end{array}$ & $\begin{array}{l}1.2 \pm \\
0.16\end{array}$ & $\begin{array}{c}10.1 \pm \\
0.8\end{array}$ & $\begin{array}{c}0.38 \pm \\
0.04\end{array}$ & $\begin{array}{l}45.2 \pm \\
7.5\end{array}$ & $\begin{array}{c}172.3 \pm \\
40.4\end{array}$ & $\begin{array}{l}2.7 \pm \\
0.49\end{array}$ & $\begin{array}{c}10.2 \pm \\
3.2\end{array}$ & $\begin{array}{c}0.18 \pm \\
0.004\end{array}$ & $\begin{array}{c}56.1 \pm \\
5.2\end{array}$ & $\begin{array}{c}101.1 \pm \\
8.5\end{array}$ & $\begin{array}{c}3.1 \pm \\
0.09\end{array}$ & $5.6 \pm 0.2$ \\
\hline $40-50$ & $\begin{array}{c}0.99 \pm \\
0.02\end{array}$ & $4.1 \pm 0.3$ & $\begin{array}{c}40.8 \pm \\
3.8\end{array}$ & $\begin{array}{l}0.3 \pm \\
0.01\end{array}$ & $3.2 \pm 0.2$ & $\begin{array}{c}0.27 \pm \\
0.03\end{array}$ & $\begin{array}{c}39.2 \pm \\
2.7\end{array}$ & $\begin{array}{c}103.9 \pm \\
6.1\end{array}$ & $\begin{array}{l}2.4 \pm \\
0.18\end{array}$ & $6.3 \pm 0.4$ & $\begin{array}{c}0.18 \pm \\
0.01\end{array}$ & $\begin{array}{c}47.8 \pm \\
1.0\end{array}$ & $\begin{array}{c}87.7 \pm \\
1.1\end{array}$ & $\begin{array}{l}3.0 \pm \\
0.25\end{array}$ & $5.5 \pm 0.3$ \\
\hline $50-60$ & $\begin{array}{c}0.86 \pm \\
0.04\end{array}$ & $3.8 \pm 0.3$ & $\begin{array}{c}32.7 \pm \\
3.4\end{array}$ & $\begin{array}{c}0.3 \pm \\
0.02\end{array}$ & $2.6 \pm 0.2$ & $\begin{array}{c}0.22 \pm \\
0.02\end{array}$ & $\begin{array}{c}46.3 \pm \\
1.7\end{array}$ & $\begin{array}{c}103.8 \pm \\
11.3\end{array}$ & $\begin{array}{l}2.5 \pm \\
0.13\end{array}$ & $5.7 \pm 0.6$ & $\begin{array}{c}0.15 \pm \\
0.01\end{array}$ & $\begin{array}{c}47.2 \pm \\
1.3\end{array}$ & $\begin{array}{c}72.2 \pm \\
4.7\end{array}$ & $\begin{array}{l}2.5 \pm \\
0.24\end{array}$ & $3.8 \pm 0.5$ \\
\hline $60-70$ & $\begin{array}{c}0.74 \pm \\
0.09\end{array}$ & $4.2 \pm 1.4$ & $\begin{array}{c}28.6 \pm \\
5.8\end{array}$ & $\begin{array}{c}0.4 \pm \\
0.12\end{array}$ & $2.4 \pm 0.5$ & $\begin{array}{c}0.66 \pm \\
0.26\end{array}$ & $\begin{array}{c}18.4 \pm \\
14.0\end{array}$ & $\begin{array}{c}49.7 \pm \\
15.6\end{array}$ & $\begin{array}{c}0.8 \pm \\
0.57\end{array}$ & $2.1 \pm 0.5$ & $\begin{array}{c}0.16 \pm \\
0.01\end{array}$ & $\begin{array}{c}45.5 \pm \\
1.3\end{array}$ & $\begin{array}{c}72.8 \pm \\
3.4\end{array}$ & $\begin{array}{l}2.3 \pm \\
0.20\end{array}$ & $3.8 \pm 0.5$ \\
\hline $70-80$ & $\begin{array}{c}0.57 \pm \\
0.11\end{array}$ & $8.7 \pm 3.8$ & $\begin{array}{c}41.7 \pm \\
9.2\end{array}$ & $\begin{array}{c}0.7 \pm \\
0.33\end{array}$ & $3.2 \pm 0.8$ & $\begin{array}{c}1.06 \pm \\
0.17\end{array}$ & $3.4 \pm 1.6$ & $\begin{array}{c}31.0 \pm \\
14.3\end{array}$ & $\begin{array}{l}0.2 \pm \\
0.07\end{array}$ & $1.6 \pm 0.5$ & $\begin{array}{c}0.28 \pm \\
0.04\end{array}$ & $\begin{array}{c}28.8 \pm \\
5.3\end{array}$ & $\begin{array}{c}74.8 \pm \\
4.2\end{array}$ & $\begin{array}{l}1.6 \pm \\
0.25\end{array}$ & $4.3 \pm 0.3$ \\
\hline $80-90$ & $\begin{array}{c}0.61 \pm \\
0.10\end{array}$ & $6.1 \pm 1.9$ & $\begin{array}{c}35.3 \pm \\
5.6\end{array}$ & $\begin{array}{c}0.4 \pm \\
0.09\end{array}$ & $2.3 \pm 0.2$ & $\begin{array}{c}1.36 \pm \\
0.16\end{array}$ & $0.9 \pm 0.4$ & $\begin{array}{c}11.4 \pm \\
4.7\end{array}$ & $\begin{array}{c}0.1 \pm \\
0.04\end{array}$ & $1.2 \pm 0.5$ & $\begin{array}{c}0.52 \pm \\
0.20\end{array}$ & $\begin{array}{c}13.6 \pm \\
2.6\end{array}$ & $\begin{array}{c}63.1 \pm \\
13.9\end{array}$ & $\begin{array}{l}0.9 \pm \\
0.15\end{array}$ & $4.0 \pm 0.8$ \\
\hline $\begin{array}{l}90- \\
100\end{array}$ & $n d$ & $n d$ & $n d$ & $n d$ & $n d$ & $\begin{array}{c}1.36 \pm \\
0.21\end{array}$ & $0.3 \pm 0.1$ & $3.7 \pm 1.2$ & $\begin{array}{c}0.03 \pm \\
0.02\end{array}$ & $0.3 \pm 0.1$ & $\begin{array}{c}1.36 \pm \\
0.44\end{array}$ & $9.4 \pm 5.2$ & $\begin{array}{c}83.6 \pm \\
9.2\end{array}$ & $\begin{array}{c}0.6 \pm \\
0.34\end{array}$ & $5.5 \pm 0.5$ \\
\hline $\begin{array}{l}\text { Total } 0 \\
-100 \\
\mathrm{~cm}\end{array}$ & & & $787.5^{a}$ & & $57.0^{\mathrm{a}}$ & & & 907.0 & & 53.1 & & & 953.7 & & 57.4 \\
\hline
\end{tabular}


All bulk density estimates exclude coarse the stone fraction $(>2 \mathrm{~mm})$ for the purposes of $\mathrm{C}$ and $\mathrm{N}$ stock calculations. ${ }^{\mathrm{a}}$ Total $\mathrm{C}$ and $\mathrm{N}$ stocks at the $\mathrm{SOC}_{\mathrm{LOW}}$ site are estimated using values from the $80-90 \mathrm{~cm}$ layer for the $90-100 \mathrm{~cm}$ layer, since sample collection from the $90-100 \mathrm{~cm}$ layer of the $\mathrm{SOC}_{\mathrm{LOw}}$ site was not possible. 